\title{
Atomic Layer Deposition of PbS Thin Films at Low Temperatures
}

\section{Popov, Georgi}

2020-10-13

pÿPopov , G , Bai , G, Mattinen , M , Manner , T , Lindström , H , Seppänen , H , Suihkonen , S , Vehkamäki , M , Kemell , M , Jalkanen, P , Mizohata , K, Räisänen , J, Leskelä , M , Koivula , H M , Barry , S T \& Ritala , M 2020 , ' Atomic Layer Deposition of PbS Thin Films at pÿLow Temperatures ' , Chemistry of Materials , vol. 32 , no. 19 , pp. 82168228 . https://doi.org/10.1021/acs.chemm

http://hdl.handle.net/10138/320868

https://doi.org/10.1021/acs.chemmater.0c01887

cc_by

publishedVersion

Downloaded from Helda, University of Helsinki institutional repository.

This is an electronic reprint of the original article.

This reprint may differ from the original in pagination and typographic detail.

Please cite the original version. 


\title{
Atomic Layer Deposition of PbS Thin Films at Low Temperatures
}

\author{
Georgi Popov,* Goran Bačíc, Miika Mattinen, Toni Manner, Hannu Lindström, Heli Seppänen, \\ Sami Suihkonen, Marko Vehkamäki, Marianna Kemell, Pasi Jalkanen, Kenichiro Mizohata, \\ Jyrki Räisänen, Markku Leskelä, Hanna Maarit Koivula, Seán T. Barry, and Mikko Ritala*
}

Cite This: Chem. Mater. 2020, 32, 8216-8228

Read Online

\section{ACCESS I Lwl Metrics \& More}

回 Article Recommendations

SI Supporting Information

ABSTRACT: Atomic layer deposition (ALD) is a viable method for depositing functional, passivating, and encapsulating layers on top of halide perovskites. Studies in that area have only focused on metal oxides, despite a great number of materials that can be made with ALD. This work demonstrates that, in addition to oxides, other ALD processes can be compatible with the perovskites. We describe two new ALD processes for lead sulfide. These processes operate at low deposition temperatures $\left(45-155^{\circ} \mathrm{C}\right)$ that have been inaccessible to previous ALD PbS processes. Our processes rely on volatile and reactive lead precursors $\mathrm{Pb}(\mathrm{dbda})\left(\mathrm{dbda}=\mathrm{rac}-\mathrm{N}^{2}, N^{3}\right.$-di-tertbutylbutane-2,3-diamide) and $\mathrm{Pb}(\text { btsa })_{2}$ (btsa $=$ bis(trimethylsilyl)amide) as well as $\mathrm{H}_{2} \mathrm{~S}$. These precursors produce high quality $\mathrm{PbS}$ thin films that are uniform, crystalline, and pure. The films exhibit p-

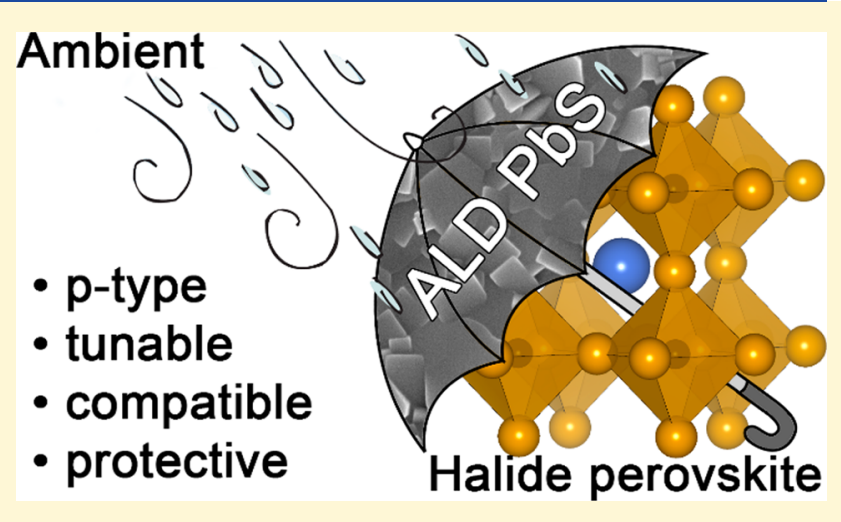
type conductivity and good mobilities of $10-70 \mathrm{~cm}^{2} \mathrm{~V}^{-1} \mathrm{~s}^{-1}$. Low deposition temperatures enable direct $\mathrm{ALD}$ of $\mathrm{PbS}$ onto a halide perovskite $\mathrm{CH}_{3} \mathrm{NH}_{3} \mathrm{PbI}_{3}$ (MAPI) without its decomposition. The stability of MAPI in ambient air is greatly improved by capping with ALD PbS. More generally, these new processes offer valuable alternatives for PbS-based devices, and we hope that this study will inspire more studies on ALD of non-oxides on halide perovskites.

\section{INTRODUCTION}

Lead(II) sulfide ( $\mathrm{PbS}$ ) is one of the oldest known and most wellstudied semiconductors. Depending on whether excess lead or sulfur is present, $\mathrm{PbS}$ exhibits either n-type or p-type semiconductivity. ${ }^{1}$ The band gap of $\mathrm{PbS}$ is narrow $(0.4 \mathrm{eV})$; therefore, $\mathrm{PbS}$ absorbs visible and near-mid-infrared light. The exciton Bohr radius in $\mathrm{PbS}$ is large (ca. $20 \mathrm{~nm}$ ) compared to most semiconductors which enables quantum confinement effects to manifest at relatively large dimensions, causing widening of the band gap. ${ }^{2}$ These unique properties enable application of $\mathrm{PbS}$ thin films in photovoltaics, ${ }^{3,4}$ photodetectors, $^{5,6}$ transistors, ${ }^{7}$ and gas sensors. ${ }^{8,9} \mathrm{PbS}$ quantum dots demonstrate an even wider range of applications. ${ }^{7}$ Atomic layer deposition (ALD) is capable of producing both $\mathrm{PbS}$ thin films ${ }^{10}$ and quantum dots. ${ }^{11}$ Our main interest in ALD of PbS is in using $\mathrm{PbS}$ thin films together with halide perovskites.

Halide perovskites are a class of materials with remarkable optoelectronic properties. Perovskites have radically changed the landscape in the photovoltaics research ${ }^{12}$ and are studied in a variety of other devices such as X-ray scintillators, ${ }^{13}$ photodetectors, ${ }^{14,15}$ light-emitting diodes (LEDs), ${ }^{16}$ and transistor ${ }^{17}$ as well as memory components. ${ }^{18,19}$ However, halide perovskites also face stability and scalability issues that hinder their commercialization. Perovskites decompose in ambient air, and scalable deposition methods must be developed for all layers in perovskite-based devices for their production. One approach to tackle these issues is to use ALD for thin film deposition while making these devices. ALD is compatible with roll-to-roll processing and is inherently scalable to large batches and deposition areas. ALD offers uniform and pinhole-free films and ability to conformally coat even the most demanding 3D structures with high aspect ratios. When deposited on top of perovskite, such films encapsulate the perovskite and improve its stability in ambient air. ${ }^{20}$ Because of these characteristics, ALD has recently made its way into perovskite photovoltaics. ${ }^{21}$ Zardetto et al., ${ }^{22}$ Seo et al., ${ }^{23}$ Brinkmann et al., ${ }^{24}$ and Raiford et $\mathrm{al}^{25}$ have given comprehensive reviews on this topic.

A great number of different materials can be deposited with ALD: at least 501 unique compositions according to the database of ALD processes. ${ }^{26}$ However, in context of ALD on perovskites, previous studies have focused on a few selected ALD oxides such as $\mathrm{Al}_{2} \mathrm{O}_{3}$ and $\mathrm{SnO}_{x^{*}}{ }^{22-24}$ This disparity is caused by the relatively high deposition temperatures (100-400 ${ }^{\circ} \mathrm{C}$ ) that most ALD processes require. These deposition

Received: May 4, 2020

Revised: September 1, 2020

Published: September 16, 2020 
(a)
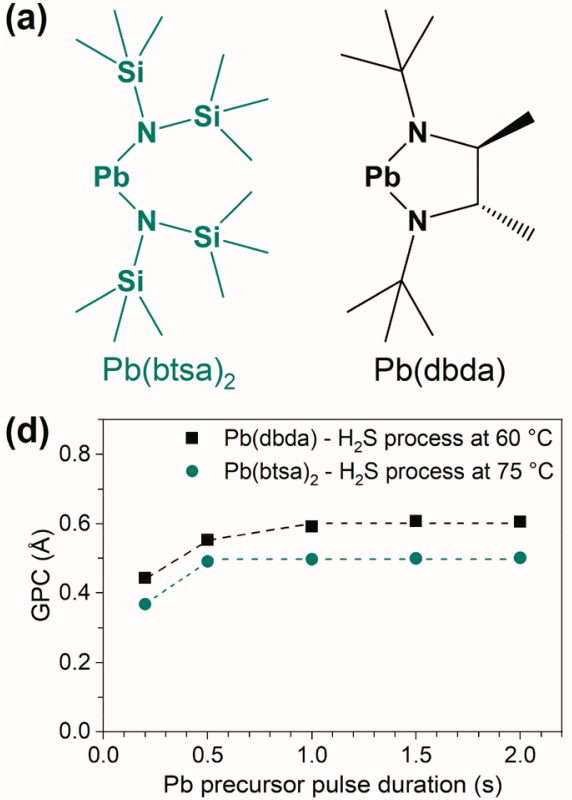

(b)

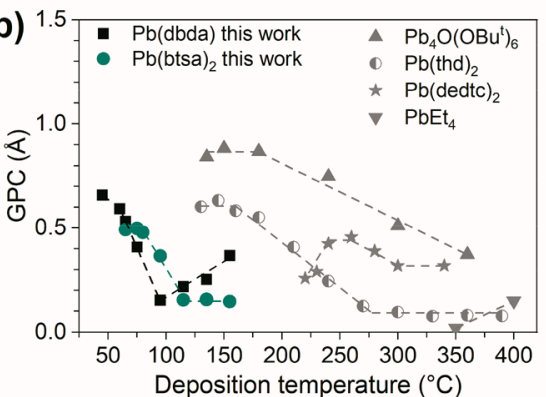

(e)

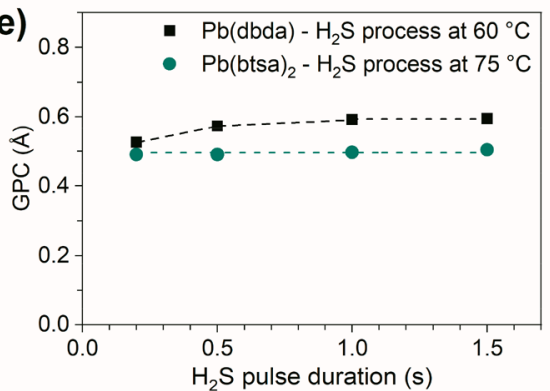

(c)

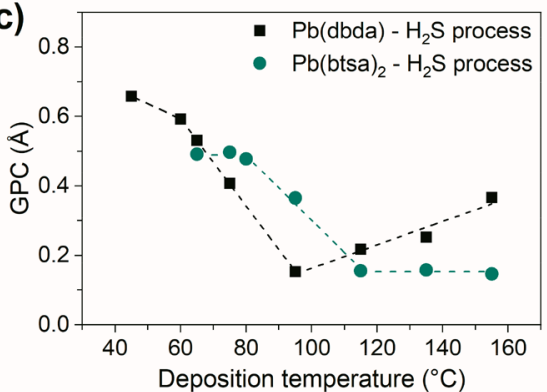

(f)

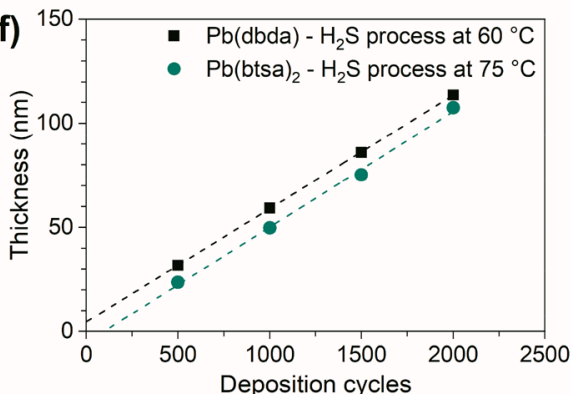

Figure 1. (a) Lead precursors used in this study. (b) Overview of ALD processes for $\mathrm{PbS}$ with $\mathrm{H}_{2} \mathrm{~S}$. For more details on $\mathrm{Pb} \mathrm{b}_{4} \mathrm{O}(\mathrm{OBu})_{6}, \mathrm{~Pb}(\text { thd })_{2}$, and $\mathrm{Pb}(\text { dedtc })_{2}$ refer to Nykänen et al. ${ }^{10}$ and on $\mathrm{PbEt}_{4}$ to Yun et al. ${ }^{28}$ Growth per cycle (GPC) of the PbS film on silicon as (c) a function of deposition temperature, (d) $\mathrm{Pb}$ precursor pulse duration, and (e) $\mathrm{H}_{2} \mathrm{~S}$ pulse duration. (f) $\mathrm{PbS}$ film thickness on silicon as a function of applied deposition cycles. Unless otherwise evident, data are from films deposited with 1000 cycles, 1.0 s precursor pulses, and purge durations.

temperatures are incompatible with the low thermal budget (ca. $\leq 100{ }^{\circ} \mathrm{C}$ ) of the perovskites. Another incompatibility issue arises from chemical reactions between the ALD precursors and the perovskites. ${ }^{27}$ In this work we show that, in addition to the handful of ALD oxide processes, also ALD sulfide processes can be compatible with the perovskites. In particular, $\mathrm{PbS}$ can be deposited directly on the $\mathrm{CH}_{3} \mathrm{NH}_{3} \mathrm{PbI}_{3}$ (MAPI) perovskite, improves the stability of the perovskite, and has valuable functional properties. We chose $\mathrm{PbS}$ because it can exhibit $\mathrm{p}$ type semiconductivity which is scarce among perovskite compatible ALD materials and because $\mathrm{PbS}$ electrical as well as optical properties can be tuned. We aimed to achieve proper protective and carrier transport properties in one ALD layer that is compatible with the perovskites. Combining two functions into one ALD layer provides the advantage of simplifying the device structure and its deposition procedure. ${ }^{29}$ Very few ALD processes are capable of depositing films with such properties, and p-type semiconductors suitable for hole transporting layers are even more scarce. ${ }^{22,25}$ Previous studies have already demonstrated the applicability of $\mathrm{PbS}$ films in perovskite photovoltaics. $^{30,31}$ We believe that protective, $\mathrm{p}$-type $\mathrm{PbS}$ can be used in other $\mathrm{p}-\mathrm{i}-\mathrm{n}$ junction based devices such as LEDs, ${ }^{16}$ memory components, ${ }^{19}$ and photodetectors. ${ }^{14,15}$ Devices based on other structures can still exploit the protective property of $\mathrm{PbS}$ provided that the conductivity of the protective layer is not detrimental. $\mathrm{PbS}$ films also have another useful property: a series of chemical treatments convert them into MAPI films while retaining the typical advantages of ALD, as demonstrated by Sutherland et al. ${ }^{32,33}$ in one of the first studies involving both perovskites and ALD.

Several ALD processes already exist for PbS (Figure $1 \mathrm{~b}) .^{10,28}$ These processes operate in a temperature range of $130-400{ }^{\circ} \mathrm{C}$. Such temperatures are incompatible with the halide perovskites. For example, MAPI, the most well-known halide perovskite, decomposes completely at $130{ }^{\circ} \mathrm{C}$ in our ALD reactors. Lowering the deposition temperature below $130{ }^{\circ} \mathrm{C}$ with the earlier ALD PbS processes is impossible because the lead precursors are either not sufficiently volatile or reactive at lower temperatures. Hence, we decided to look into developing new ALD processes for $\mathrm{PbS}$ that would work at lower temperatures. In our previous work on ALD of $\mathrm{PbI}_{2}{ }^{34}$ we had identified one lead precursor that is volatile and reactive at low temperatures: lead(II) bis[bis(trimethylsilyl)amide], $\mathrm{Pb}(\text { btsa })_{2}$ (Figure 1a). Another potentially suitable precursor, also a diamide, lead(II) rac- $N^{2}, N^{3}$-di-tert-butylbutane-2,3-diamide, $\mathrm{Pb}(\mathrm{dbda})$ (Figure 1a), was recently reported by Bačic et al. ${ }^{35}$ In this work we describe two new ALD processes for $\mathrm{PbS}$ using $\mathrm{Pb}(\mathrm{btsa})_{2}$ and $\mathrm{Pb}(\mathrm{dbda})$ as lead precursors and $\mathrm{H}_{2} \mathrm{~S}$ as a sulfur precursor. We also demonstrate that these $\mathrm{PbS}$ processes are compatible with MAPI films and discuss challenges that we encountered during the scale-up of the $\mathrm{Pb}(\mathrm{dbda})$ synthesis.

\section{RESULTS AND DISCUSSION}

2.1. Precursor Characteristics, Synthesis, and ScaleUp. $\mathrm{Pb}(\mathrm{btsa})_{2}$ and $\mathrm{Pb}(\mathrm{dbda})$ (Figure 1a) are diamidoplumbylenes with low melting points (32 and $53{ }^{\circ} \mathrm{C}$, respectively) and high volatility $\left(60\right.$ and $40^{\circ} \mathrm{C}$ precursor source temperatures in the F120 ALD reactor, respectively). While $\mathrm{Pb}(\text { btsa })_{2}$ was readily scalable through a facile salt-metathesis reaction, $\mathrm{Pb}(\mathrm{dbda})$ had only been synthesized on a preparative scale by transamination of $\mathrm{Pb}(\mathrm{btsa})_{2} \cdot{ }^{35}$ ALD process development required larger quantities of $\mathrm{Pb}(\mathrm{dbda})$, and scale-up uncovered deficiencies in the original procedure. We found that residual $\mathrm{Pb}(\text { btsa })_{2}$ as low as $5 \%$ in the crude product mixture after the transamination lowered the melting point mixture to far below room temperature. All attempts to separate $\mathrm{Pb}(\mathrm{dbda})$ and $\mathrm{Pb}(\text { btsa })_{2}$ by recrystallization failed, and fractional sublimation was complicated by their similar volatility. While $\mathrm{Pb}(\mathrm{dbda})$ sublimed first, the partial pressure of $\mathrm{Pb}(\mathrm{btsa})_{2}$ rose when $\mathrm{Pb}(\mathrm{dbda})$ was depleted in the sublimation pot; thus, $\mathrm{Pb}(\mathrm{btsa})_{2}$ began to sublime and mix with crystalline $\mathrm{Pb}(\mathrm{dbda})$ on the coldfinger. This caused the crystalline $\mathrm{Pb}(\mathrm{dbda})$ to become a 
(a)

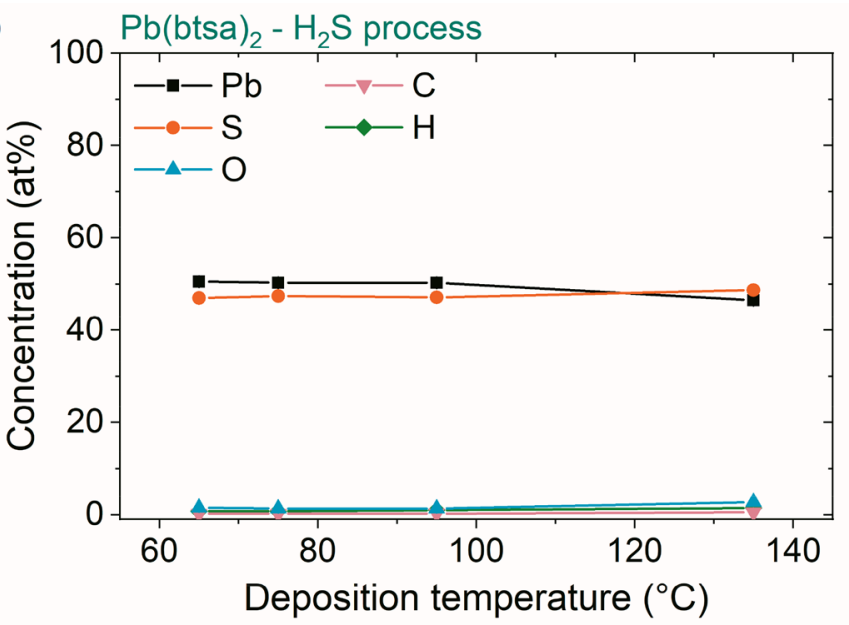

(c)

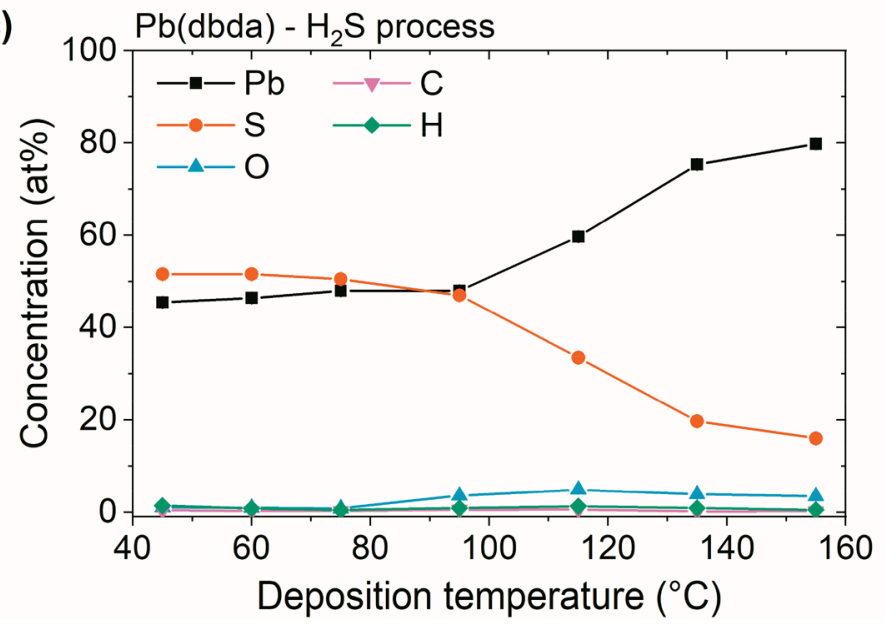

(b)

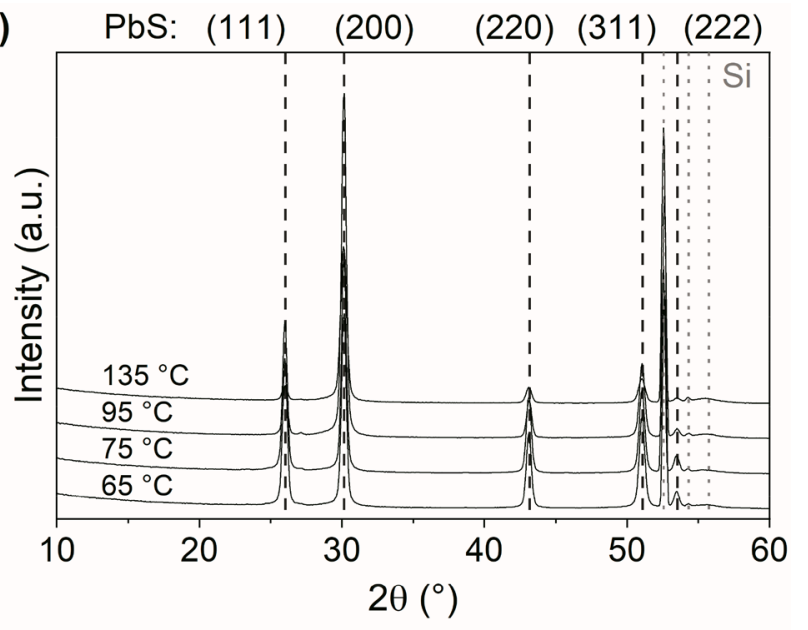

(d)

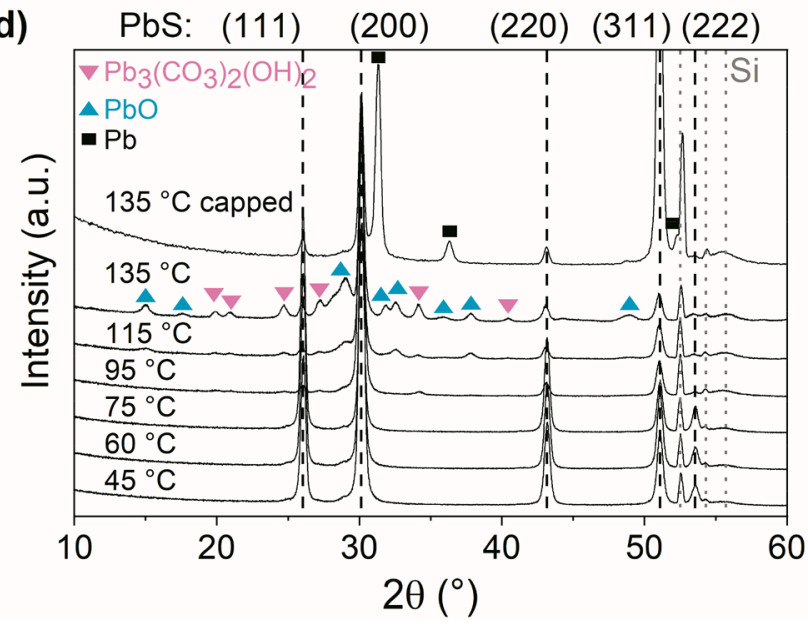

Figure 2. TOF-ERDA composition of ca. $100 \mathrm{~nm}$ thick $\mathrm{PbS}$ films deposited at different temperatures with (a) $\mathrm{Pb}(\mathrm{btsa})_{2}$ and $(\mathrm{c}) \mathrm{Pb}(\mathrm{dbda})$. For more details on impurity contents see Figure S5. Grazing incidence XRD (GIXRD) patterns of PbS films deposited at different temperatures with (b) $\mathrm{Pb}(\text { btsa })_{2}$ and (d) $\mathrm{Pb}(\mathrm{dbda})$. Dashed black and dotted gray lines mark $\mathrm{PbS}$ and substrate $(\mathrm{Si})$ reflection positions, respectively. $135^{\circ} \mathrm{C}$ capped refers to a $\mathrm{PbS}$ film capped with ca. $3 \mathrm{~nm} \mathrm{ALD} \mathrm{Al}_{2} \mathrm{O}_{3}$ and measured immediately after the deposition. $\mathrm{PbS}$ films were deposited with $1.0 \mathrm{~s}$ precursor pulses and purge durations. In (b) and (d) films were deposited with 1000 cycles, except for the $135^{\circ} \mathrm{C}$ capped film that was deposited with 2000 cycles.

molten mixture that would drip back into the pot indefinitely. Thus, all $\mathrm{Pb}(\mathrm{btsa})_{2}$ must either be converted to $\mathrm{Pb}(\mathrm{dbda})$ or destroyed by thermolysis for effective purification. Reaction monitoring by ${ }^{1} \mathrm{H}$ NMR spectroscopy allowed us to scale-up and hasten the preparation: we reduced the reaction time (from ca. 24 to $3 \mathrm{~h}$ ) by increasing the reaction temperature (ca. $110^{\circ} \mathrm{C}$ ) and using toluene as solvent. Ensuring that no $\mathrm{Pb}(\mathrm{btsa})_{2}$ remained by reaction monitoring enabled simple $\mathrm{Pb}(\mathrm{dbda})$ sublimation. We obtained reduced yield ( $51 \%$ on a $10 \mathrm{~g}$ scale), but larger quantities of pure $\mathrm{Pb}(\mathrm{dbda})$ could be prepared in a timely manner. Optimization of the kinetic conditions for this reaction currently lies outside the scope of this work but is the subject of ongoing research.

2.2. $\mathrm{PbS}$ Film Growth. Both $\mathrm{Pb}(\text { btsa })_{2}$ and $\mathrm{Pb}(\mathrm{dbda})$, in combination with $\mathrm{H}_{2} \mathrm{~S}$, produced $\mathrm{PbS}$ films at low deposition temperatures (Figure 1c and Figure S1). The deposition temperature ranges that we explored were limited by the precursor source temperatures on the lower end and by the precursor decomposition temperatures on the higher end. The $\mathrm{Pb}(\mathrm{btsa})_{2}-\mathrm{H}_{2} \mathrm{~S}$ process has two regions where the GPC is independent of the deposition temperature. In this process the GPC decreases toward higher temperatures. We attribute the GPC decrease to the surface passivation by $-\mathrm{SiMe}_{3}$ groups, forming from the protonated btsa ligand, that becomes more effective at higher temperatures. ${ }^{36}$ In the $\mathrm{Pb}(\mathrm{dbda})-\mathrm{H}_{2} \mathrm{~S}$ process, at first, the GPC also decreases with increasing deposition temperature, but at temperatures higher than 95 ${ }^{\circ} \mathrm{C}$ the GPC starts to increase again. This increase is related to the changes in film composition that will be discussed later.

We studied the influence of the process parameters on the film deposition in more detail at the deposition temperatures of 75 and $60{ }^{\circ} \mathrm{C}$ with $\mathrm{Pb}(\text { btsa })_{2}$ and $\mathrm{Pb}(\mathrm{dbda})$, respectively. At these temperatures, in both processes, the GPC saturates with respect to the $\mathrm{Pb}$ precursor as well as $\mathrm{H}_{2} \mathrm{~S}$ pulse durations (Figure $1 \mathrm{~d}, \mathrm{e}$ ) and is unaffected by the duration of the nitrogen purge (Figure S2). The thickness of the film is straightforwardly adjustable due to its linear dependence on the number of deposition cycles on both silicon (Figure 1f) and sapphire (Figure S3). The films are surprisingly uniform for such low temperatures and short pulse and purge durations. The thickness nonuniformities over the $5 \times$ $5 \mathrm{~cm}^{2}$ substrate are $3.9 \%$ and $4.4 \%$ with $\mathrm{Pb}(\mathrm{btsa})_{2}$ and $\mathrm{Pb}(\mathrm{dbda})$, respectively (Figure $\mathrm{S} 4$ ). These values are similar to those of the TMA $-\mathrm{H}_{2} \mathrm{O}$ alumina process $(2.4 \%$, Figure $\mathrm{S} 4 \mathrm{c})$ and other metal sulfide processes such as $\mathrm{SnS}_{2},{ }^{37} \mathrm{ZrS}_{2}$, and $\mathrm{HfS}_{2}{ }^{38}$ in the same cross-flow F120 ALD reactor but at much higher temperatures.

2.3. Film Composition and Crystallinity. The $\mathrm{Pb}(\mathrm{btsa})_{2}-$ $\mathrm{H}_{2} \mathrm{~S}$ process produces crystalline and nearly stoichiometric lead sulfide films in a wide temperature range (Figure 2a,b). The films 
are the purest at the lowest deposition temperatures with a total impurity content of ca. 2 at. \% that increases slightly toward higher deposition temperatures (Figure S5a). Typical time-offlight elastic recoil detection analysis (TOF-ERDA) elemental depth profiles are shown in Figure S5c,d. Also, the $\mathrm{Pb}(\mathrm{dbda})-$ $\mathrm{H}_{2} \mathrm{~S}$ process deposits the purest films at the lowest deposition temperatures (Figure $\mathrm{S} 5 \mathrm{~b}$ ), but the stoichiometry changes significantly above $95^{\circ} \mathrm{C}$ where the films contain more lead than sulfur (Figure 2c). XRD patterns of these lead-rich films expose reflections of impurity phases: $\mathrm{PbO}$ and $\mathrm{Pb}_{3}\left(\mathrm{CO}_{3}\right)_{2}(\mathrm{OH})_{2}$ (Figure 2d).

2.4. Formation of $\mathrm{Pb}$ Using $\mathrm{Pb}(\mathrm{dbda})$. The presence of oxygen-containing phases in the XRD patterns was startling because the precursors did not contain oxygen. We speculated that at higher temperatures $\mathrm{Pb}(\mathrm{dbda})$ decomposes into elemental lead which would explain the changes in the stoichiometry of the films. When these films are exposed to ambient air, the elemental lead can react with $\mathrm{O}_{2}, \mathrm{CO}_{2}$, or $\mathrm{H}_{2} \mathrm{O}$ in air, producing the oxygen-containing phases observed in the XRD patterns. To test this hypothesis, we capped a film deposited at $135{ }^{\circ} \mathrm{C}$ with ca. $3 \mathrm{~nm} \mathrm{ALD} \mathrm{Al}_{2} \mathrm{O}_{3}$ (TMA- $\mathrm{H}_{2} \mathrm{O}$ process) without breaking the vacuum and measured the XRD pattern immediately after removing the film from the reactor. Indeed, the XRD pattern of the capped film lacked reflections of the oxygen-containing phases and instead had reflections of elemental lead (Figure 2d).

Even though the presence of elemental lead supports our hypothesis on decomposition of $\mathrm{Pb}(\mathrm{dbda})$, it is still inconsistent with the higher thermal decomposition temperature (ca. 160 ${ }^{\circ} \mathrm{C}$ ) reported for $\mathrm{Pb}(\mathrm{dbda})$ in the literature ${ }^{35}$ - our own observation that signs of $\mathrm{Pb}(\mathrm{dbda})$ thermal decomposition (blackening of the hot end of the precursor source tube) in the F120 ALD reactor appear only at $\geq 155^{\circ} \mathrm{C}$ - and an experiment where at $135{ }^{\circ} \mathrm{C}$ we pulsed only $\mathrm{Pb}(\mathrm{dbda})$ without $\mathrm{H}_{2} \mathrm{~S}$ that yielded no deposit at all. Additionally, a set of depositions at 135 ${ }^{\circ} \mathrm{C}$ revealed that the process still works in an ALD regime with GPC saturating with respect to precursor pulse durations and films being visually uniform (Figures S6 and S7e). These observations suggest that elemental lead is formed by a mechanism that involves $\mathrm{H}_{2} \mathrm{~S}$ rather than thermal decomposition of $\mathrm{Pb}(\mathrm{dbda})$. In $\mathrm{Pb}(\mathrm{dbda})$ lead has an oxidation state of +2 , and therefore lead ion must be reduced and another species must be oxidized We speculated that the the oxidized species is sulfide $\left(\mathrm{S}^{2-}\right)$ and that it oxidizes to elemental sulfur, which is volatile enough to be removed during the deposition. It is not uncommon for $\mathrm{H}_{2} \mathrm{~S}$ to act as a reducing agent in ALD of transition metal dichalcogenides and reduce the metal ions in metal pentachlorides such as $\mathrm{MoCl}_{5}{ }^{39}$ and $\mathrm{ReCl}_{5}{ }^{40}$ to a lower oxidation state. This speculation is further supported by the fact that sulfur is sufficiently volatile at the temperatures and conditions being discussed; for example, Tripathi et al. used elemental sulfur as a precursor at a source temperature of $115^{\circ} \mathrm{C}$ in ALD of copper sulfide, ${ }^{41}$ in the same F120 ALD reactor as used here.

While reduction by $\mathrm{H}_{2} \mathrm{~S}$ accounts for some of our empirical observations, it does not explain the difference between the two lead precursors. To understand the cause of that difference, we evaluated the thermodynamics of the reduction with gas-phase density functional theory (DFT, def2-QZVPP// $\omega$ B97X$\mathrm{D} 3(\mathrm{BJ}) /$ def2-SVP), correcting for the gas-to-solid transition of $\mathrm{Pb}$ and $\mathrm{PbS}$ with literature thermochemical data. These calculations indicate that reduction with $\mathrm{H}_{2} \mathrm{~S}$ with concomitant elimination of elemental sulfur is nonspontaneous, in direct contradiction to the initially proposed mechanism (Table S1). To elucidate a plausible mechanism for the elemental lead formation, we then considered several other reactions such as film etching by the free ligand and formation of sulfur diamides. Of these candidates, only one fit with our empirical observations by requiring $\mathrm{H}_{2} \mathrm{~S}$ and being spontaneous for $\mathrm{Pb}(\mathrm{dbda})$ but not $\mathrm{Pb}(\text { btsa })_{2}$. That reaction is similar to the precursor thermolysis that yields elemental lead and $N$-tert-butylacetaldimine (nonspontaneous, $\Delta G=56 \mathrm{~kJ} / \mathrm{mol}$ ); however, the consequent thiolysis of the imine to produce thioacetaldehyde which further oligomerizes to a heterocyclic trithiane makes this pathway sponatenous $(\Delta G=-10 \mathrm{~kJ} / \mathrm{mol}$, Scheme 1$)$. While this

Scheme 1. Proposed Pathway for Deposition of Elemental Lead with $\mathrm{Pb}(\mathrm{dbda})$

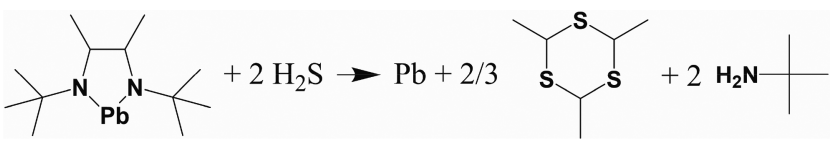

speculative mechanism fulfills all the requirements, we emphasize that it, or any alternative, would require a dedicated in situ mechanism study for verification. We believe that such a study, while outside of the scope of this work, would improve understanding of processes occurring in low-temperature deposition of lead materials with amide precursors.

The possibility of depositing elemental $\mathrm{Pb}$ with ALD at low temperatures without using a dedicated reducing agent is intriguing. We briefly explored whether that is possible by adjusting the process parameters. The $\mathrm{PbS}$ to $\mathrm{Pb}$ intensity ratios were unaffected by changes in the $\mathrm{H}_{2} \mathrm{~S}$ pulse or purge durations (Figure $\mathrm{S} 7 \mathrm{a}, \mathrm{b})$. In contrast, increasing the $\mathrm{Pb}(\mathrm{dbda})$ pulse duration increased the intensity from the $\mathrm{Pb}$ phase (Figure $\mathrm{S} 7 \mathrm{c}, \mathrm{d})$. However, even with 15 s pulse duration some $\mathrm{PbS}$ was still present. The film with the highest $\mathrm{Pb}$ content had a low resistivity of $1.0 \mathrm{~m} \Omega \mathrm{cm}(\mathrm{Pb}$ bulk resistivity $0.02 \mathrm{~m} \Omega \mathrm{cm}$ ), resembled rough metallic films in appearance, and consisted of large micrometer-sized grains connected by smaller submicrometer-sized grains (Figure S7e,f).

2.5. Film Morphology. Formation of elemental lead at higher temperatures in the $\mathrm{Pb}(\mathrm{dbda})-\mathrm{H}_{2} \mathrm{~S}$ process affects also the morphology of the films. Films deposited at lower temperatures by both processes consist of small cube-shaped grains (Figure 3a) as is characteristic to $\mathrm{PbS}$. The grains increase in size with increasing deposition temperature in the $\mathrm{Pb}(\mathrm{btsa})_{2}-$ $\mathrm{H}_{2} \mathrm{~S}$ process (Figure 3a and Figure S8), which linearly increases the roughness of the films with the deposition temperature (Figure $3 b)$. In the $\mathrm{Pb}(\mathrm{dbda}) \mathrm{H}_{2} \mathrm{~S}$ process, in addition to the cubic grains growing in size, irregularly shaped lumps start to appear (Figure 3a and Figure S9) at higher deposition temperatures. These lumps increase in size more rapidly with the deposition temperature than the cubic grains, and this in turn causes an exponential increase in the roughness of the films (Figure 3b).

2.6. Electrical Properties. Hall effect measurements revealed that both processes yield conductive p-type $\mathrm{PbS}$ films (Figure $3 \mathrm{c}$ ). The hole mobilities are $10-70 \mathrm{~cm}^{2} \mathrm{~V}^{-1} \mathrm{~s}^{-1}$ (Figure $3 \mathrm{~d}$ ) and are comparable to or exceed the mobilities of semiconductors typically used in perovskite based devices, both organic such as PEDOT:PSS $\left(2 \mathrm{~cm}^{2} \mathrm{~V}^{-1} \mathrm{~s}^{-1}\right)^{42}$ and spiroMeOTAD $\left(2 \times 10^{-3} \mathrm{~cm}^{2} \mathrm{~V}^{-1} \mathrm{~s}^{-1}\right)^{43}$ as well as inorganic such as $\mathrm{NiO}\left(10 \mathrm{~cm}^{2} \mathrm{~V}^{-1} \mathrm{~s}^{-1}\right) .4$ 

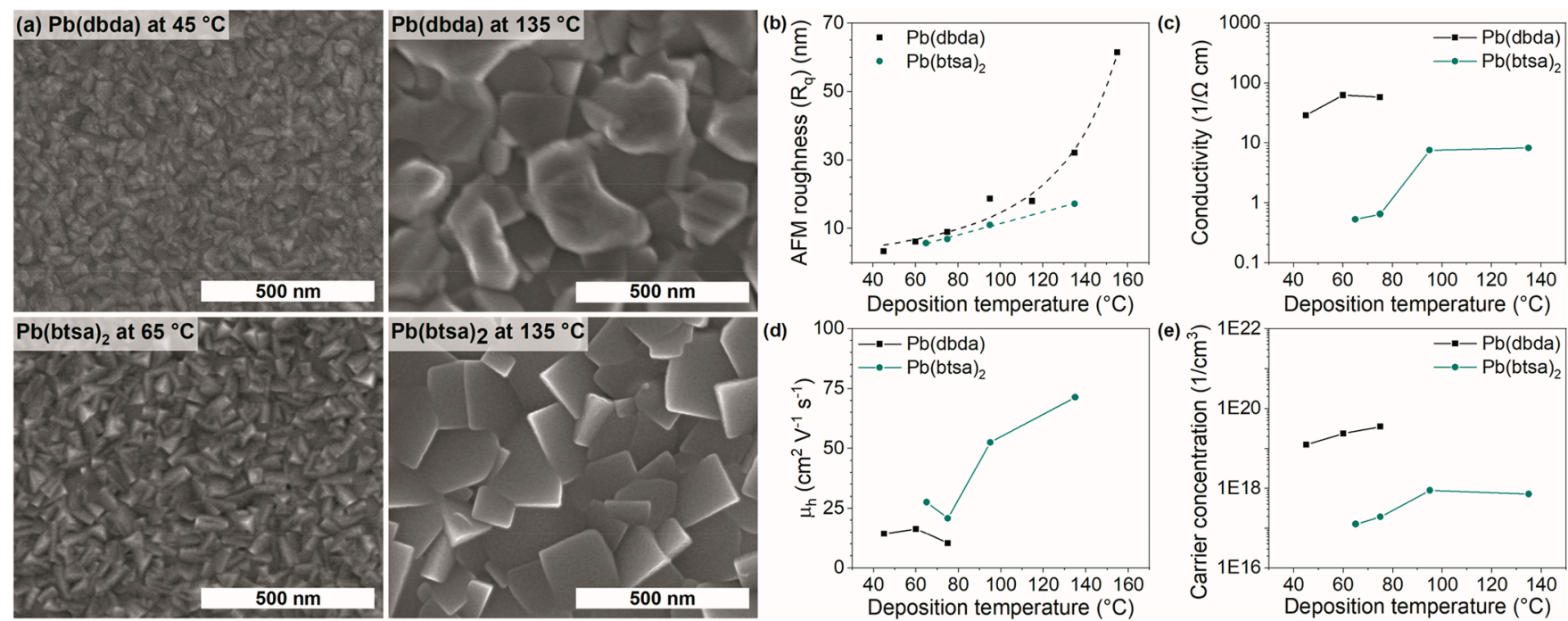

Figure 3. (a) FESEM images of $\mathrm{PbS}$ films deposited at different temperatures (see also Figures $\mathrm{S} 8$ and $\mathrm{S} 9$ ). (b) AFM roughness $R_{\mathrm{q}}$, (c) conductivity, (d) hole mobility, and (e) carrier concentration of the PbS films as a function of deposition temperature. The substrate was silicon in (a, b) and sapphire in (c, e). Films were ca. $100 \mathrm{~nm}$ thick and were deposited with $1.0 \mathrm{~s}$ precursor pulses and purge durations.

(a)

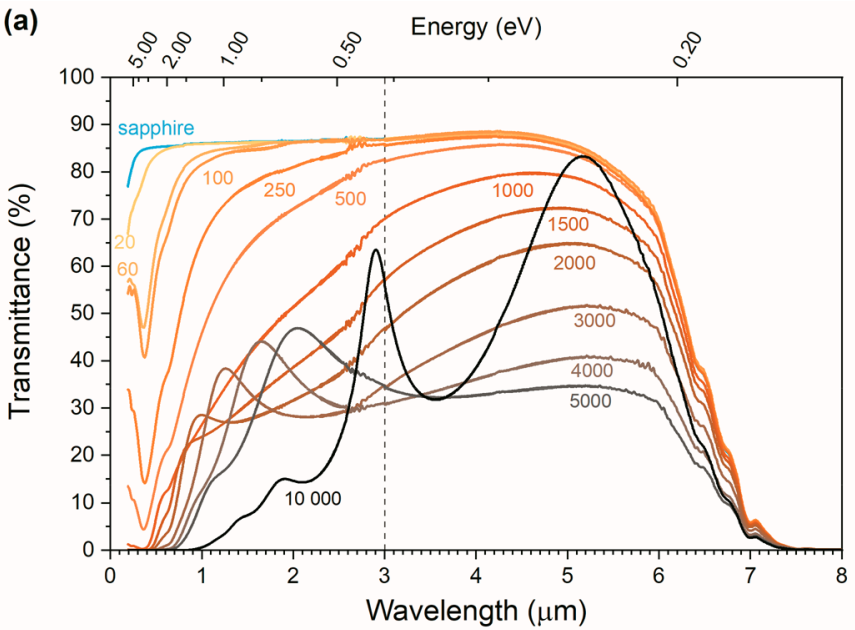

(d)
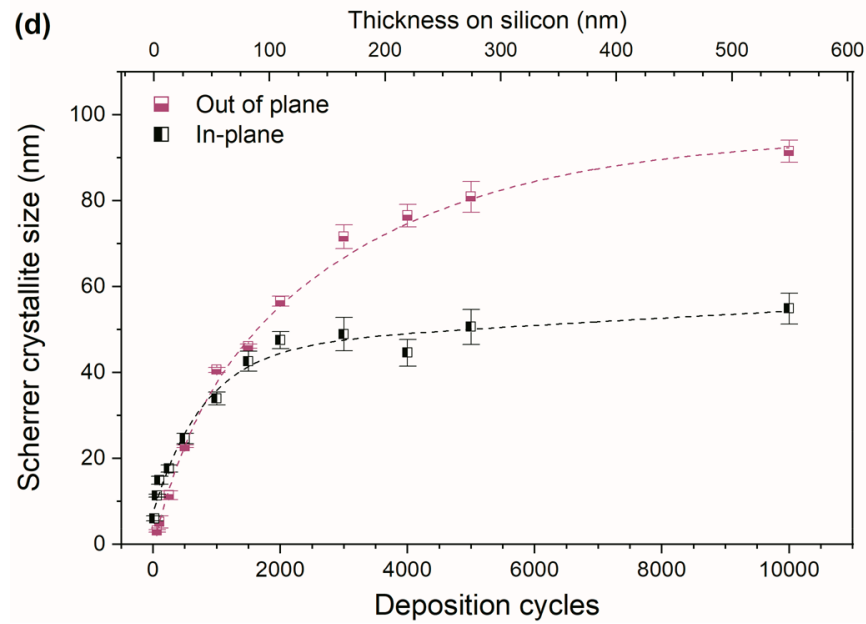

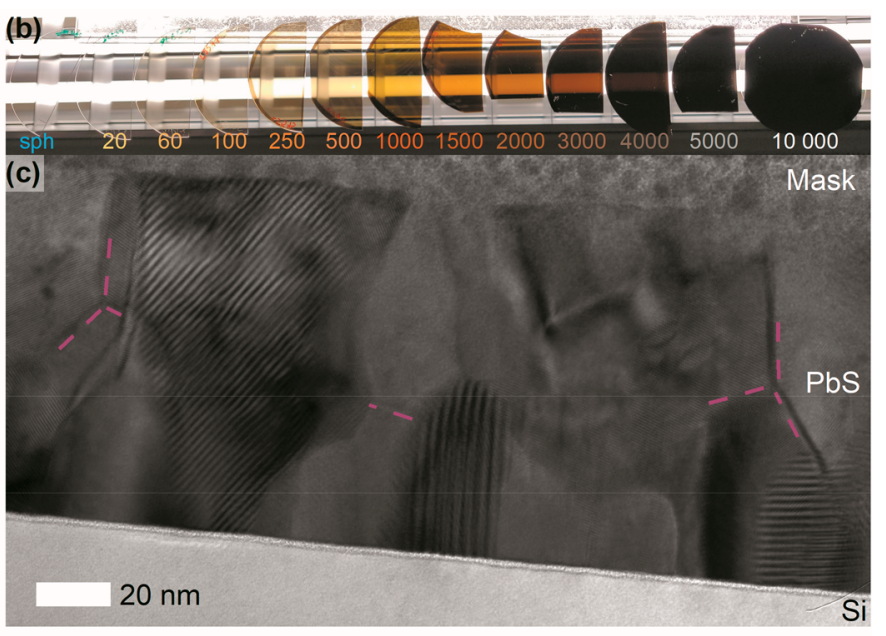

(e)

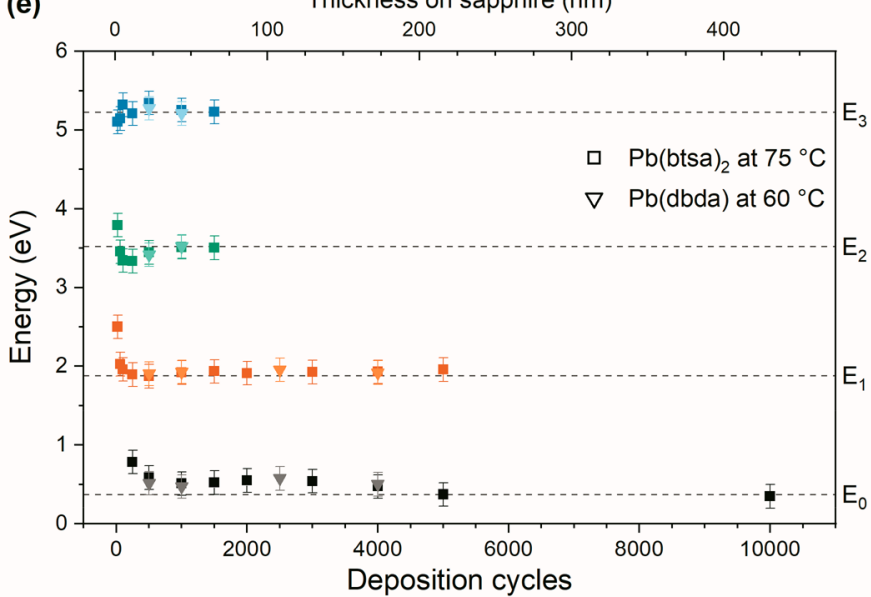

Figure 4. (a) Transmittance of $\mathrm{PbS}$ films deposited on sapphire with $\mathrm{Pb}(\mathrm{btsa})_{2}$ and different number of deposition cycles at $75^{\circ} \mathrm{C}$. The dashed gray line separates wavelength ranges measured with different instruments. (b) Photograph of the films in (a) viewed against an office lamp. (c) Crosssection TEM image of a PbS film deposited with $\mathrm{Pb}(\mathrm{btsa})_{2}$ at $75^{\circ} \mathrm{C}$ with 2000 cycles. Some grain boundaries are marked with dashed lines. (d) Out-ofplane and in-plane crystallite sizes, as measured with $\mathrm{XRD}$, in $\mathrm{PbS}$ films deposited with $\mathrm{Pb}(\mathrm{btsa})_{2}$ at $75{ }^{\circ} \mathrm{C}$ with different number of cycles. (e) Transition energies defined from $\log (1 / T)$ plots (Figure $S 14 a, c)$, including the band gap $E_{0}$. Dashed gray lines are reference energy values by Cardona et al. ${ }^{66}$ All films were deposited with $1.0 \mathrm{~s}$ pulse and purge durations. 
2.6.1. $\mathrm{Pb}$ (btsa) $)_{2}$. In the $\mathrm{PbS}$ films deposited with $\mathrm{Pb}(\text { btsa })_{2}$, hole mobility, conductivity, and carrier concentration increase at higher deposition temperatures (Figure $3 c-e$ ). We attribute the changes to the enlargement of grains (Figure $3 \mathrm{a}$ ) and to the increase of sulfur and oxygen concentrations in the films (Figure 2a, Figure S5a, and Table S2). Enlargement of grains reduces grain boundary density, which in turn increases mobility, ${ }^{45,46}$ whereas the excess of sulfur and oxygen result in defects that increase hole concentrations. ${ }^{1,47}$ All chalcogens, when in excess, are known to be p-type dopants in lead chalcogenides. ${ }^{48,49}$ The observed changes in composition are on the order of $10^{20}$ atoms $\mathrm{cm}^{-3}$ and are larger by a factor of 100 compared to the observed carrier concentrations. We speculate that this difference could be caused by carbon and hydrogen impurities because defects created by these impurities can decrease hole concentration. Overall, the observed carrier concentrations are a result of all defects created by nonstoichiometry and impurities. ${ }^{50}$ However, describing the interactions of these defects and their effect on carrier concentration is beyond this study.

2.6.2. $\mathrm{Pb}(\mathrm{dbda})$. The presence of several phases in the films deposited with $\mathrm{Pb}(\mathrm{dbda})$ at higher temperatures (Figure $2 \mathrm{~d}$ ) prevents drawing unambiguous conclusions about their electrical properties. At lower deposition temperatures the changes in grain sizes and composition are not significant enough (Figure $2 \mathrm{c}$ and Figure $59 \mathrm{a}-\mathrm{c}$ ) to cause major differences in electrical properties of these films (Figure $3 c-e$ ). Compared to $\mathrm{Pb}(\mathrm{btsa})_{2}, \mathrm{~Pb}(\mathrm{dbda})$ yields films with a conductivity larger by a factor of 100 (Figure 3c). The difference in conductivity arises from a difference in carrier concentration (Figure 3e). We attribute these differences to the excess of sulfur and lower impurity contents in the films made with $\mathrm{Pb}(\mathrm{dbda})$ at lower temperatures (Figure $2 c$ and Figure S5b). The differences in the electrical properties between the two ALD processes offers flexibility for the design of devices based on semiconductor junctions. Various postdeposition annealing treatments can provide additional control over the electrical properties of $\mathrm{PbS}^{51}$

2.7. Optical Properties. We expected that the large exciton radius (ca. $20 \mathrm{~nm}$ ) of $\mathrm{PbS}$, its narrow band gap, and the dependence of the grain size on the deposition temperature in our processes would allow us to deposit films with tailorable optical properties. To explore this hypothesis, we measured transmittance of $\mathrm{PbS}$ films deposited on sapphire in the 190$8000 \mathrm{~nm}$ range (Figure 4a,b and Figure S10a-c) and determined their optical band gaps. Optical band gaps are commonly determined from Tauc plots constructed from transmittance data, and for $\mathrm{PbS}$ thin films many examples of this approach are present in the literature (Table S3). ${ }^{6,52-65}$ However, we found optical band gap extraction from Tauc plots to be problematic in the case of $\mathrm{PbS}$. The values extracted from Tauc plots of $\sim 100 \mathrm{~nm}$ thick PbS films deposited at different temperatures were unreasonably large $(\geq 2.5 \mathrm{eV}$, Figure S10df) for the observed grain sizes (Figures S8, S9, and S11). The grains could also be confined in the film thickness direction, which is not visible in top-down SEM. We initially assumed that the grains are columnar and extend through the entire film thickness; however, TEM revealed that this is not the case, and there are also grain boundaries through film thickness (Figure 4c) - despite that the grains are still too large to explain the Tauc values.

The grains observed with microscopy methods can consist of smaller crystallites, which in turn if sufficiently small would explain the Tauc values. We calculated crystallite sizes using the
Scherrer equation and XRD data measured out-of-plane $(\theta-2 \theta)$ and in-plane $(2 \theta \chi)$, respectively (Figure S12), for the films deposited with $\mathrm{Pb}(\text { btsa })_{2}$. In the $100 \mathrm{~nm}$ thick films deposited at different temperatures the in-plane crystallite size increased significantly with increasing deposition temperature, from $47 \pm$ $3 \mathrm{~nm}$ at $65{ }^{\circ} \mathrm{C}$ to $135 \pm 33 \mathrm{~nm}$ at $135^{\circ} \mathrm{C}$, whereas the out-ofplane crystallite size remained almost unchanged at ca. $56 \mathrm{~nm}$ (Figure S13). The dependence of the in-plane crystallite size on the deposition temperature is in good agreement with the observed morphology (Figure S8) and trends in electrical properties (Figure 3 ). The out-of-plane XRD patterns show that in these films most crystallites are $\{200\}$ oriented with some minor $\{111\}$ and $\{220\}$ components. Correspondingly, the most prominent reflections in the in-plane patterns of these films are also $\{200\}$ (Figure S12c). In the films deposited at $75^{\circ} \mathrm{C}$ with different number of cycles both the out-of-plane and inplane crystallite sizes increase rapidly with the increasing number of cycles until 1500 cycles (Figure 4d). After 1500 cycles, the growth of the in-plane crystallite size slows down considerably, whereas the growth of the out-of-plane crystallite size continues and approaches the limit that can be measured from peak broadening. The XRD patterns also reveal changes in the film texture. In the out-of-plane direction $\{200\}$ dominates up to 2000 cycles and $\{111\}$ afterward, whereas in the in-plane direction also $\{200\}$ dominates up to 2000 cycles, then $\{111\}$ at 3000 cycles, and $\{220\}$ afterward.

The crystallite dimensions we observed imply no quantum confinement effects in the films deposited with 500 cycles or more and are therefore in disagreement with the Tauc values. Others have also noted a similar discrepancy between the Tauc values and crystallite sizes but provided no explanation. ${ }^{52,53}$ Additionally, there is an inconsistency between the reported Tauc values and electronic band gaps. Dasgupta et al. determined the electronic band gap of ALD PbS films using scanning tunneling microscopy (STM). ${ }^{67}$ These measurements showed that the electronic band gap decays non-linearly with increasing film thickness and approaches the bulk value when the film thickness is $16 \mathrm{~nm}$, which is in line with the exciton Bohr radius of $\mathrm{PbS}$ (ca. $20 \mathrm{~nm}$ ).

The cause of the conflicting evidence is elucidated in the earlier works of Gibson, ${ }^{68,69}$ Scanlon, ${ }^{70}$ and Cardona et al. ${ }^{66}$ on the optical and electronic properties of $\mathrm{PbS}$. Examination of $\mathrm{PbS}$ transmittance or reflectance in a wide energy range $(0.2-20 \mathrm{eV})$ reveals several band-to-band transitions in addition to the lowest energy transition, i.e., the band gap or $E_{0}$. Cardona et al. give a comprehensive list of these transitions $\left(E_{0}\right.$ to $\left.E_{6}\right)$ as well as estimate some of the energies of these transitions using reflectance and transmittance spectra from single crystals and epitaxial thin films. In the case of thin film transmittance spectra, the transition energies were estimated based on the position of the features in the $\log (1 / T)$ plot. In fact, $\log (1 / T)$ plots of our films are strikingly similar to Cardona et al. (Figure S14a-d) and contain four features corresponding to the interband transitions $E_{0}-E_{3}$. The optical band gap of thicker films ( $>500$ deposition cycles) defined from $\log (1 / T)$ plots is ca. $0.5 \mathrm{eV}$ (Figure $4 \mathrm{e}$ and Figure $\mathrm{S} 14 \mathrm{e}$ ). This value is in excellent agreement with the reported bulk band gap and electronic band gap of $\mathrm{PbS}$, whereas the increase of the interband transition energies in very thin films ( $<500$ deposition cycles) is in excellent agreement with decrease of crystallite size below the exciton radius $(20 \mathrm{~nm})$ in these films (Figure 4d,e).

To summarize, a Tauc plot is not an ideal method for determining the optical band gap of $\mathrm{PbS}$. The Tauc plot 


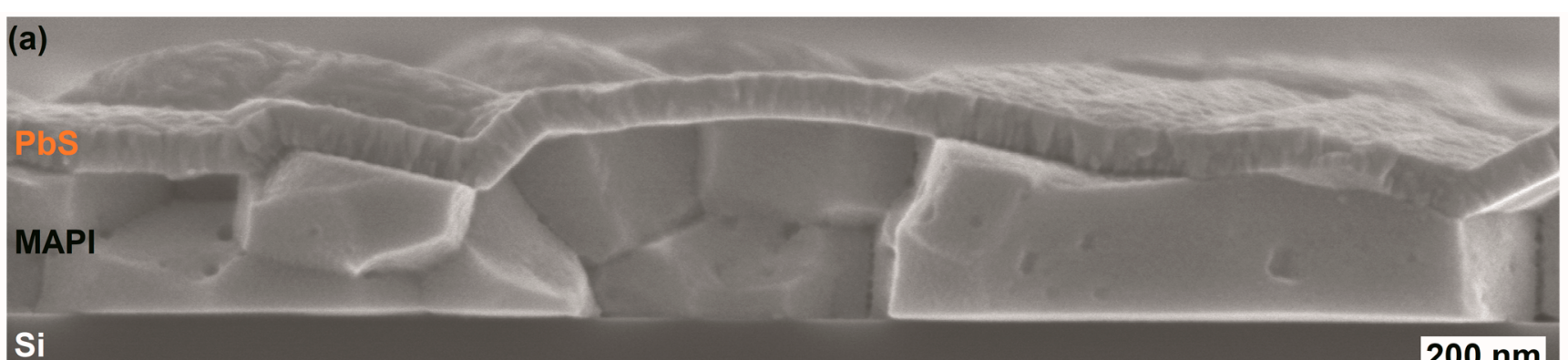

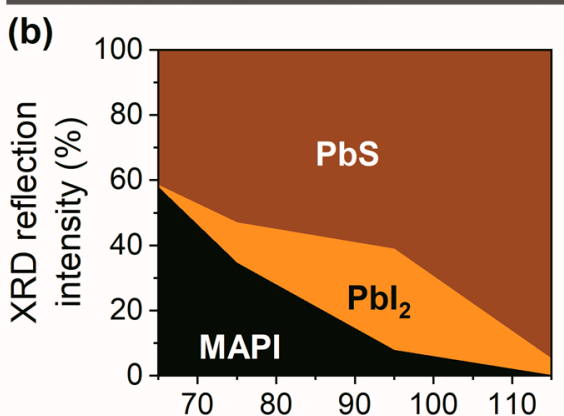

PbS deposition temperature with $\mathrm{Pb}$ (btsa) $)_{2}\left({ }^{\circ} \mathrm{C}\right)$

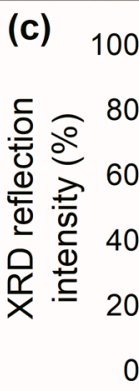

$50 \quad 60 \quad 70 \quad 80 \quad 90100110$
$\mathrm{PbS}$ deposition temperature
with $\mathrm{Pb}(\mathrm{dbda})\left({ }^{\circ} \mathrm{C}\right)$

$\mathrm{Pb}_{3}\left(\mathrm{CO}_{3}\right)_{2}(\mathrm{OH})_{2}$

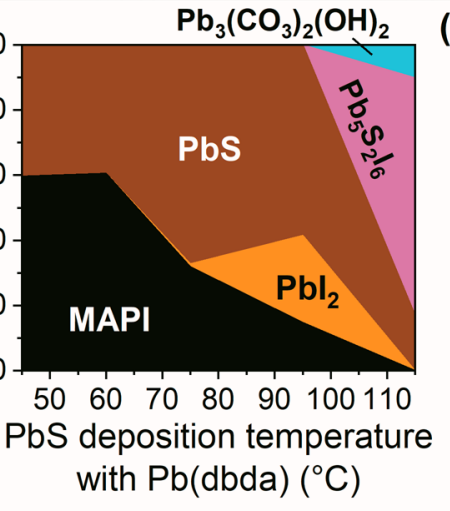

$200 \mathrm{~nm}$

(e)

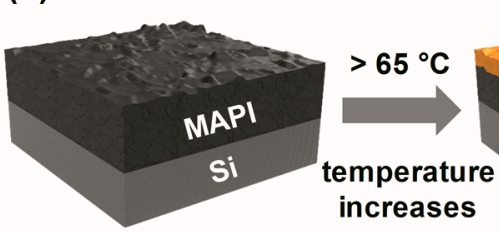

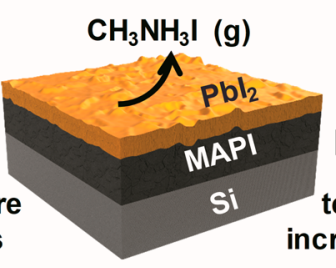

(d)

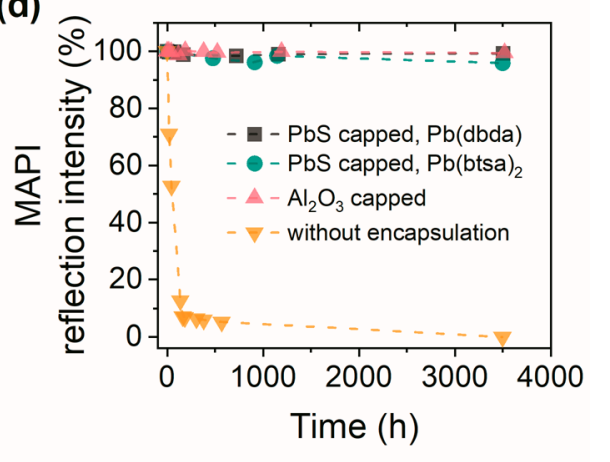

Figure 5. (a) Cross-section SEM image of a PbS-capped MAPI used for stability study in (d). PbS was deposited with Pb(dbda). To examine the cross section, the sample was broken in half after being stored in air for 413 days. For EDS line scans across the cross section see Figure S19. Relative reflection intensities (area) of crystalline phases observed in GIXRD patterns of samples where $\mathrm{PbS}$ was deposited on MAPI films with (b) $\mathrm{Pb}(\mathrm{btsa})_{2}$ and $(\mathrm{c}) \mathrm{Pb}(\mathrm{dbda})$ at different temperatures. (b) and (c) are derived from GIXRD patterns in Figures S16 and S17. MAPI film reflection intensity (d) as a function of storage time in ambient air (open system) with and without different capping films derived from GIXRD patterns in Figures S18-S22. $\mathrm{PbS}$ capping film was deposited at $45^{\circ} \mathrm{C}$ with $\mathrm{Pb}(\mathrm{dbda})$ and at $65^{\circ} \mathrm{C}$ with $\mathrm{Pb}(\mathrm{btsa}){ }_{2}$. The $\mathrm{Al}_{2} \mathrm{O}_{3}$ capping film was deposited at $65^{\circ} \mathrm{C}$ with $800 \mathrm{cycles}$ of the TMA- $\mathrm{H}_{2} \mathrm{O}$ process using a $1.0 \mathrm{~s}$ precursor pulse and $4.0 \mathrm{~s}$ purge durations. The capping film thicknesses were 66,50 , and $52 \mathrm{~nm}$ for $\mathrm{PbS}$ deposited with $\mathrm{Pb}(\mathrm{dbda}), \mathrm{PbS}$ deposited with $\mathrm{Pb}(\mathrm{btsa})_{2}$, and $\mathrm{Al}_{2} \mathrm{O}_{3}$, respectively. $\mathrm{PbS}$ films in (b), (c), and (d) were deposited with 1000 cycles, 1.0 s precursor pulses, and purge durations. (e) Schematic of the changes occurring on the MAPI film in the ALD reactor when deposition temperatures higher than 65 ${ }^{\circ} \mathrm{C}$ are used.

guidelines available in the literature suggest deriving the band gap from the most noticeable Tauc property $\left((\alpha h \nu)^{2}\right)$ change, ${ }^{71}$ which in our case yielded unreasonably large values. However, in optical spectra the most noticeable feature does not necessarily correspond to the band gap $\left(E_{0}\right)$. For $\mathrm{PbS}$ the most noticeable feature is $E_{2}$ (Figures S10d,e and $\left.S 14 a-d, f\right) .{ }^{66}$ The Tauc property itself provides an additional challenge for narrow gap materials as it accentuates higher energy transitions and masks lower energy transitions (Figure S14f-h). Logarithmic plots of Tauc property can reveal these hidden transitions and enable extraction of their energies. In the case of our Tauc plots in addition to $E_{2}$ we were able to find also $E_{0}$ (ca. $0.5 \mathrm{eV}$ ) and $E_{1}$ (ca. $1.6 \mathrm{eV}$ ) by extensive rescaling (Figure $\mathrm{S} 14 \mathrm{~g}, \mathrm{~h}$ ). We note the similarity between the $E_{1}$ and $E_{2}$ transitions energies extracted from Tauc plots and the band gaps reported in the literature for $\mathrm{PbS}$ thin films that are also extracted from Tauc plots (Table S3). An accurate distinction of the band gap transition from the other higher energy interband transitions from optical data requires examination of said data in a wide energy range that also covers the region of the bulk band gap of $\mathrm{PbS}(0.2-1.0 \mathrm{eV})$. In our case $\log (1 / T)$ plots were more robust than the Tauc plots for this purpose. The transitions observed in optical data are best understood in terms of the band structure of $\mathrm{PbS}$, for which we refer the reader to Albanesi et al. ${ }^{72}$

2.8. Deposition of PbS onto Halide Perovskites. We investigated whether the ALD processes developed and described here are compatible with halide perovskites. When sulfides are deposited onto perovskites, there is a possibility of an anion exchange between the perovskite and $\mathrm{H}_{2} \mathrm{~S}$ (eq 1).

$$
\mathrm{CH}_{3} \mathrm{NH}_{3} \mathrm{PbI}_{3}(\mathrm{~s})+\mathrm{H}_{2} \mathrm{~S}(\mathrm{~g}) \rightarrow \mathrm{CH}_{3} \mathrm{NH}_{3} \mathrm{I}(\mathrm{g})+2 \mathrm{HI}(\mathrm{g})+\mathrm{PbS}(\mathrm{s})
$$

However, based on thermodynamic values reported in the literature, ${ }^{73-75}$ that reaction is endothermic $(\Delta H=146 \mathrm{~kJ} / \mathrm{mol})$ and unfavorable $(\Delta G=121 \mathrm{~kJ} / \mathrm{mol}$ at RT). In addition, it was experimentally verified that the MAPI film was unaffected when $\mathrm{H}_{2} \mathrm{~S}$ was pulsed onto it at $50{ }^{\circ} \mathrm{C}$ (Figure $\mathrm{S} 15$ ). We deposited $\mathrm{PbS}$ films at different temperatures on MAPI films (Figure 5a) and used XRD to examine the state of the MAPI film after the deposition. In the case of the $\mathrm{Pb}(\text { btsa })_{2}-\mathrm{H}_{2} \mathrm{~S}$ process only the lowest deposition temperature of $65{ }^{\circ} \mathrm{C}$ left the MAPI film unchanged (Figure $5 \mathrm{~b}$ and Figure S16). At deposition 
temperatures higher than $65^{\circ} \mathrm{C} \mathrm{PbI}_{2}$ reflections appeared and increased in intensity, whereas MAPI reflections decreased in intensity. This is caused by the decomposition of MAPI into $\mathrm{PbI}_{2}$ and volatile $\mathrm{CH}_{3} \mathrm{NH}_{3} \mathrm{I}$ upon heating to the target deposition temperature before $\mathrm{PbS}$ deposition begins (Figure 5e). When the $\mathrm{PbS}$ deposition temperature was above $95{ }^{\circ} \mathrm{C}$, also the intensity of $\mathrm{PbI}_{2}$ reflections decreased. This decrease is caused by the evaporation of $\mathrm{PbI}_{2}$ before the $\mathrm{PbS}$ deposition.

MAPI films remained unchanged when $\mathrm{PbS}$ was deposited on them with $\mathrm{Pb}(\mathrm{dbda})$ in the temperature range $45-60{ }^{\circ} \mathrm{C}$ (Figure 5c and Figure S17). At the deposition temperature of 75 ${ }^{\circ} \mathrm{C}$ and higher, MAPI expectedly decomposed into $\mathrm{CH}_{3} \mathrm{NH}_{3} \mathrm{I}$ and $\mathrm{PbI}_{2}$, as in the case when $\mathrm{Pb}(\text { btsa })_{2}$ was used. At the deposition temperature of $95{ }^{\circ} \mathrm{C}$ and higher reflections of $\mathrm{Pb}_{5} \mathrm{~S}_{2} \mathrm{I}_{6}$ and $\mathrm{Pb}_{3}\left(\mathrm{CO}_{3}\right)_{2}(\mathrm{OH})_{2}$ phases appeared (Figure S17). The appearance of these phases coincides with the onset of formation of elemental $\mathrm{Pb}$. Notably, no $\mathrm{Pb}_{5} \mathrm{~S}_{2} \mathrm{I}_{6}$ was observed with $\mathrm{Pb}(\text { btsa })_{2}$. These results imply that the species involved in the formation of elemental $\mathrm{Pb}$ can react with the $\mathrm{PbI}_{2}$ remaining from the decomposition of the MAPI film to yield $\mathrm{Pb}_{5} \mathrm{~S}_{2} \mathrm{I}_{6}$. The $\mathrm{Pb}_{3}\left(\mathrm{CO}_{3}\right)_{2}(\mathrm{OH})_{2}$ phase is apparently formed upon exposure of $\mathrm{Pb}_{5} \mathrm{~S}_{2} \mathrm{I}_{6}$ or $\mathrm{Pb}$ to the ambient air.

In the case of $\mathrm{PbS}$ deposition on MAPI the $\mathrm{Pb}(\mathrm{dbda})-\mathrm{H}_{2} \mathrm{~S}$ process is superior to the $\mathrm{Pb}(\text { btsa })_{2}-\mathrm{H}_{2} \mathrm{~S}$. $\mathrm{Pb}(\mathrm{dbda})$ offers a 20 ${ }^{\circ} \mathrm{C}$ wide temperature window where $\mathrm{PbS}$ can be deposited on MAPI, whereas $\mathrm{Pb}(\text { btsa })_{2}$ only provides a single useful deposition temperature of $65{ }^{\circ} \mathrm{C}$. The benefit of the wider temperature window comes with the cost of more complicated synthesis. Therefore, $\mathrm{Pb}(\mathrm{btsa})_{2}$ can be a more convenient choice for perovskites that can withstand higher deposition temperatures such as $\mathrm{FA}_{x} \mathrm{MA}_{1-x} \mathrm{~Pb}\left(\mathrm{Br}_{y} \mathrm{I}_{1-y}\right)_{3}$ (up to $120{ }^{\circ} \mathrm{C}$ ), ${ }^{76}$ $\mathrm{Cs}_{x} \mathrm{FA}_{1-x} \mathrm{~Pb}\left(\mathrm{Br}_{y} \mathrm{I}_{1-y}\right)_{3}$ (up to $110{ }^{\circ} \mathrm{C}$ ), ${ }^{77}$ and others. ${ }^{24} \mathrm{On}$ the contrary, the deposition of $\mathrm{Pb}$ makes $\mathrm{Pb}(\mathrm{dbda})$ less relevant at higher deposition temperatures. Ultimately, the need of certain electrical properties can dictate which of the two processes is more suitable in a specific device design.

2.9. Application of PbS as a Protective Layer. Finally, to determine whether encapsulation with an ALD PbS film can protect halide perovskites from the ambient air, we followed the state of PbS-capped MAPI films with XRD. Without any encapsulation, the MAPI film completely decomposed into $\mathrm{PbI}_{2}$ in a week, and after 5 months, $\mathrm{PbI}_{2}$ had further reacted into $\mathrm{PbIOH}$ (Figure 5d and Figure S18). On the other hand, MAPI films were stable for at least 5 months in air when encapsulated with $\mathrm{PbS}$ films deposited either from $\mathrm{Pb}(\mathrm{btsa})_{2}$ or $\mathrm{Pb}(\mathrm{dbda})$ (Figures S20 and S21). For comparison, we also evaluated the stability of a MAPI film encapsulated with $\mathrm{ALD} \mathrm{Al}_{2} \mathrm{O}_{3}$ film deposited with the TMA- $\mathrm{H}_{2} \mathrm{O}$ process (Figure S22). The improvement in the MAPI stability provided by the $\mathrm{PbS}$ encapsulation equals that provided by an $\mathrm{Al}_{2} \mathrm{O}_{3}$ film of similar thickness (Figure 5c).

We attempted to further characterize the barrier properties of our films by depositing them on $50 \mu \mathrm{m}$ thick biaxially oriented poly(ethylene terephthalate) (BoPET) and measuring water vapor (WVTR) and oxygen transmission rates (OTR) of these samples. However, film deposition on BoPET was challenging. Relatively long pulse $(6 s)$ and purge times $(3 s)$ were required for visually uniform films on BoPET, and the GPC was significantly lower than on rigid substrates: $0.20 \AA$ with $\mathrm{Pb}$ (btsa $)_{2}$ at $65^{\circ} \mathrm{C}$ and $0.25 \AA$ with $\mathrm{Pb}(\mathrm{dbda})$ at $45^{\circ} \mathrm{C}$. With the $\mathrm{PbS}$ capping the OTR decreased by ca. $90 \%$ with respect to the bare BoPET, however, the WVTR decreased only slightly (Figure S23). We also observed a significant decrease in the
OTR and only a slight decrease in the WVTR of the reference BoPET samples coated with $\mathrm{ALD} \mathrm{Al}_{2} \mathrm{O}_{3}$. These results indicate that $\mathrm{ALD} \mathrm{PbS}$ and $\mathrm{Al}_{2} \mathrm{O}_{3}$ coatings perform similarly in these barrier tests, despite the polycrystalline structure of the $\mathrm{PbS}$. In general, it is thought that amorphous films will serve as better barriers because they lack grain boundaries along which diffusion can be faster. $^{78} \mathrm{~A}$ thin amorphous passivating $\mathrm{PbSO}_{3} / \mathrm{PbSO}_{4}$ layer that forms on the $\mathrm{PbS}$ surface ${ }^{79}$ can account for the $\mathrm{Al}_{2} \mathrm{O}_{3}$ comparable barrier performance of our crystalline $\mathrm{PbS}$ films.

While low deposition temperatures enable the use of polymers as substrates, the ALD of barrier films on polymers is not straightforward. This is partially because of the engineering challenges associated with the handling of flexible substrates (see Figure S24) but even more because of the complex mechanism of ALD film nucleation and growth on polymers. ${ }^{80}$ Barrier performance of an ALD film is affected by many factors such as porosity, roughness, and surface structure of the substrate polymer as well as crystallinity, impurity content, and thickness of the coating itself. ${ }^{81}$ For instance, a thicker coating could block gases more efficiently and be more mechanically durable but could also crack more easily, whereas a thinner coating would not necessarily form a continuous and tight layer. ${ }^{80-82}$ In the literature WVTR values as low as $10^{-1} \mathrm{~g}$ $\mathrm{m}^{-2}$ day $^{-1}$ were reported for $50 \mathrm{~nm}$ thick thermal ALD $\mathrm{Al}_{2} \mathrm{O}_{3}$ films deposited at $65{ }^{\circ} \mathrm{C}$ on thicker $(125 \mu \mathrm{m})$ PET substrates ${ }^{83}$ and even lower ones for $\mathrm{ALD} \mathrm{Al}_{2} \mathrm{O}_{3}$ on rigid substrates measured with electrical calcium corrosion tests. ${ }^{84}$ On the basis of the literature results and our own observations, we anticipate that further optimization of the pretreatment, process, and handling parameters will enable lower WVTR values for ALD PbS coatings on polymers. However, the extent of optimizing these parameters is a topic of a dedicated study and outside of the scope of this work which aimed to demonstrate the ability of $\mathrm{ALD} \mathrm{PbS}$ films to protect halide perovskite films on rigid substrates.

\section{CONCLUSIONS}

We described two new ALD processes for deposition of $\mathrm{PbS}$ films using $\mathrm{Pb}(\mathrm{btsa})_{2}, \mathrm{~Pb}(\mathrm{dbda})$, and $\mathrm{H}_{2} \mathrm{~S}$ as precursors. The scale-up of $\mathrm{Pb}(\mathrm{dbda})$ synthesis afforded reasonable precursor purity and quantity for process development. Yet challenges encountered during the scale-up highlight the importance of further studies on the synthetic chemistry of volatile $\mathrm{Pb}$ complexes. Both $\mathrm{Pb}$ precursors enable deposition of high quality $\mathrm{PbS}$ films at low temperatures of $65-155^{\circ} \mathrm{C}$ with $\mathrm{Pb}(\text { btsa })_{2}$ and $45-75{ }^{\circ} \mathrm{C}$ with $\mathrm{Pb}(\mathrm{dbda})$. The $\mathrm{PbS}$ films are uniform, crystalline, and of high purity as well as conductive and p-type. We demonstrated that at deposition temperatures of $\leq 65{ }^{\circ} \mathrm{C}$ these ALD processes are compatible with the perovskite halide $\left(\mathrm{CH}_{3} \mathrm{NH}_{3} \mathrm{PbI}_{3}\right)$ films. $\mathrm{Pb}(\mathrm{dbda})$ is more suitable for capping the $\mathrm{CH}_{3} \mathrm{NH}_{3} \mathrm{PbI}_{3}$ perovskite because it is applicable in a range of temperatures versus only one temperature with $\mathrm{Pb}(\mathrm{btsa})_{2}$. $\mathrm{Pb}(\mathrm{btsa})_{2}$, on the other hand, is a more suitable choice for perovskites that withstand higher temperatures such as those based on cesium or formamidinium as well as in cases where high carrier mobility is sought. Capping the $\mathrm{CH}_{3} \mathrm{NH}_{3} \mathrm{PbI}_{3}$ films with ALD PbS prevents the perovskite from decomposing in the ambient air. The encapsulation performance of ALD PbS is comparable to $\mathrm{ALD} \mathrm{Al}_{2} \mathrm{O}_{3}$. Compatibility with various substrates such as polymers provided by the low deposition temperatures and the ability to control electrical and optical properties of the $\mathrm{PbS}$ films offer flexibility for design of device 
structures based on halide perovskites or $\mathrm{PbS}$. We hope that this work will encourage other studies on the use of non-oxide ALD films together with halide perovskites and that the new ALD PbS processes are viable options for PbS based devices.

\section{EXPERIMENTAL SECTION}

4.1. Precursor Synthesis. Lead(II) bis[bis(trimethylsilyl) amide] $\left(\mathrm{Pb}(\mathrm{btsa})_{2}\right)$ was synthesized from lead(II) chloride (Alfa Aesar, 99.999\%) and lithium bis(trimethylsilyl)amide (Li(btsa), Aldrich, $95 \%$ ) as previously described. ${ }^{34,85}$ Lead(II) $r a c-N^{2}, N^{3}$-di-tert-butylbutane-2,3-diamide $(\mathrm{Pb}(\mathrm{dbda}))$ was prepared by a modified literature procedure. ${ }^{35} \mathrm{~Pb}$ (btsa) $(13.160 \mathrm{~g}, 24.923 \mathrm{mmol})$ was dissolved in 100 $\mathrm{mL}$ of toluene at ambient temperature under nitrogen in a $200 \mathrm{~mL}$ Schlenk flask to yield a clear orange solution. Then, free rac-N,N'-ditert-butyl-2,3-diaminobutane $\left(\mathrm{H}_{2} \mathrm{dbda}, 5.000 \mathrm{~g}, 24.94 \mathrm{mmol}\right)$ diluted in $10 \mathrm{~mL}$ of toluene was added all at once via cannula. Some decomposition was evident as the mixture turned dark green-gray with the precipitation of metallic $\mathrm{Pb}$. The mixture was then immediately heated to reflux in an oil bath to facilitate the transamination reaction. Aliquots were taken by syringe and placed into an NMR tube under nitrogen; the majority of solvent was removed under vacuum; then $\mathrm{C}_{6} \mathrm{D}_{6}$ was added to prepare the sample for spectroscopy. In this way, the reaction was monitored by ex situ ${ }^{1} \mathrm{H}$ NMR spectroscopy until the signal for $\mathrm{Pb}(\mathrm{btsa})_{2}$ had disappeared $(\mathrm{ca} .3 \mathrm{~h})$. The reaction mixture was then cooled to ambient temperature, and volatiles (i.e., free bis(trimethylsilyl)amine and toluene) were removed under high vacuum (ca. $10^{-2}$ Torr) until a blood-red oil remained. Most of the unreacted $\mathrm{H}_{2} \mathrm{dbda}$ was removed by distillation through a $90^{\circ}$ glass elbow under high vacuum $\left(40^{\circ} \mathrm{C} / 10^{-2}\right.$ Torr $)$ into a dry ice-acetone cooled $\left(-78^{\circ} \mathrm{C}\right)$ receiving Schlenk flask. The almost complete removal of $\mathrm{H}_{2} \mathrm{dbda}$ was conveniently indicated by solidification of the mixture in the pot. After the receiving flask was replaced with a clean Schlenk flask, the crude product was purified by sublimation $\left(60^{\circ} \mathrm{C}, 10^{-2}\right.$ Torr $)$ into the air-cooled elbow to yield $\mathrm{Pb}(\mathrm{dbda})$ ( $5.1 \mathrm{~g}, 51 \%$, based on $\left.\mathrm{Pb}(\mathrm{btsa})_{2}\right)$ as a blood-red crystalline solid. Remaining ligands and solvent were condensed into the dry ice-acetone cooled receiving flask and removed mechanically. Samples prepared in this way had identical spectroscopic and physical properties to those previously reported. ${ }^{35}$

4.2. Film Deposition. Caution! $\mathrm{H}_{2} \mathrm{~S}$ is a flammable, corrosive, and highly toxic gas. The ALD reactor used in this work was in a dedicated laboratory equipped with an $\mathrm{H}_{2} \mathrm{~S}$ sensor and where gas masks were readily available. The $\mathrm{H}_{2} \mathrm{~S}$ bottle was kept in a gas cabinet with isolated ventilation. EPDM (ethylene propylene diene monomer) rubber seals were used. The exhaust was bubbled though an aqueous solution of $\mathrm{Cu}\left(\mathrm{NO}_{3}\right)_{2}$. The authors urge the readers to acquaint themselves with the article by Dasgupta et al. ${ }^{86}$ before working with $\mathrm{H}_{2} \mathrm{~S}$.

The films were deposited in a commercial, hot-wall, flow-type F120 ALD reactor (ASM Microchemistry Ltd.) operated under reduced pressure of ca. 10 mbar. A continuous flow $(400 \mathrm{sccm})$ of nitrogen (AGA, 99.999\%), introduced into the reactor through a gas purifier (SAES Pure Gas, MC1-902F, $\mathrm{H}_{2} \mathrm{O}, \mathrm{O}_{2}, \mathrm{CO}, \mathrm{CO}_{2}, \mathrm{H}_{2}$, NMHC removal $<1 \mathrm{ppb})$, was used as a carrier and purge gas. $\mathrm{Pb}(\text { btsa })_{2}$ and $\mathrm{Pb}(\mathrm{dbda})$ were sublimed from open glass boats held inside the reactor at 60 and $40{ }^{\circ} \mathrm{C}$, respectively. For both precursors the first signs of decomposition were observed at deposition temperatures of $155{ }^{\circ} \mathrm{C} . \mathrm{H}_{2} \mathrm{~S}$ (Linde, 99.5\%) was introduced into the reactor through a gas purifier (SAES Pure Gas, $\mathrm{MC1}-302 \mathrm{~F}, \mathrm{H}_{2} \mathrm{O}$ removal $<1 \mathrm{ppb}$ ) and a needle valve, at a flow rate of $14 \mathrm{sccm} . \mathrm{Al}_{2} \mathrm{O}_{3}$ was deposited by using the trimethylaluminum (TMA) $-\mathrm{H}_{2} \mathrm{O}$ process. The films were deposited on $5 \times 5$ $\mathrm{cm}^{2}$ silicon (100), soda lime glass, and biaxially oriented poly(ethylene terephthalate) (BoPET, GoodFellow, $50 \mu \mathrm{m}$ thick) substrates as well as on 2 in. sapphire wafers (c-plane off to $M$-plane by $0.2 \pm 0.1^{\circ}$, double side polished, University Wafer). For the deposition on BoPET a special adapter was machined from $\mathrm{Al}$ sheets to prevent the movement of the polymer substrate by pressing it at the edges, without the adapter the movement of the polymer occasionally blocked the gas flows in the deposition chamber (Figure S24).

$\mathrm{CH}_{3} \mathrm{NH}_{3} \mathrm{PbI}_{3}$ films were made by a conversion of $\mathrm{PbI}_{2}$ films. First $\mathrm{PbI}_{2}$ films were deposited with $\mathrm{ALD}$ at $75{ }^{\circ} \mathrm{C}$ with the $\mathrm{Pb}(\mathrm{btsa})_{2}-\mathrm{SnI}_{4}$ process (Acros Organics, $>99 \%,-10$ mesh) $)^{34}$ Then a TLC plate $(0.75$ $\mathrm{mL} / \mathrm{g}$ pore volume silica gel on Al foil, Sigma-Aldrich) was submerged in a $500 \mathrm{mg} / \mathrm{mL}$ solution of $\mathrm{CH}_{3} \mathrm{NH}_{3} \mathrm{I}(>99.0 \%, \mathrm{TCI})$ in dimethylformamide ( $\geq 99.9 \%$, Sigma-Aldrich) for $30 \mathrm{~min}$. The TLC plate was then dried in air by keeping it on a $60^{\circ} \mathrm{C}$ hot plate for $30 \mathrm{~min}$. The dry plate was placed on the bottom of a steel cylinder $(V=0.5 \mathrm{~L})$ with the MAI permeated $\mathrm{SiO}_{2}$ side facing up. An aluminum support holding the $\mathrm{PbI}_{2}$ film face down was then placed on the TLC plate. The design of the aluminum support is such that the distance between the MAI permeated $\mathrm{SiO}_{2}$ face of the TLC plate and the surface of the $\mathrm{PbI}_{2}$ film was ca. $1 \mathrm{~mm}$. After the loading the cylinder was cycled with $\mathrm{N}_{2}$ (AGA, 99.999\%)/vacuum three times and isolated with vacuum inside (ca. 1 mbar). The evacuated cylinder was heated in an air oven at $140^{\circ} \mathrm{C}$ for $24 \mathrm{~h}$ to complete the conversion of $\mathrm{PbI}_{2}$ to $\mathrm{CH}_{3} \mathrm{NH}_{3} \mathrm{PbI}_{3}$.

4.3. Film Characterization. Prior to characterization, the films were stored in closed containers filled with ambient air unless indicated otherwise. No significant oxidation is expected for $\mathrm{PbS}$ stored in air, ${ }^{79,87,88}$ but instead a thin (ca. $0.5 \mathrm{~nm}$ ) passivating $\mathrm{PbSO}_{3} / \mathrm{PbSO}_{4}$ layer can form upon prolonged exposure. ${ }^{79}$

Film thicknesses were measured with X-ray reflectivity (XRR, Rigaku SmartLab diffractometer). To measure XRR thickness maps, slits were used to limit the irradiated area ${ }^{89}$ to $\leq 5 \times 4 \mathrm{~mm}^{2}$ (at the angle range of interest), and an automated $X Y$ stage was used to measure a $7 \times 7$ matrix across the $5 \times 5 \mathrm{~cm}^{2}$ samples with $0.5 \mathrm{~cm}$ edge exclusion. Grazing incidence XRD (GIXRD) patterns were measured at $1^{\circ}$ incidence angle. Grain sizes were calculated by using the Scherrer equation and full width at half-maximum of the most intense reflection. Scherrer constants from Langford and Wilson et al. ${ }^{90}$ were used for the respective lattice planes assuming cubic crystallites. The instrumental broadening was defined by measuring $\mathrm{PbS}$ powder (99.9\%, SigmaAldrich) out-of-plane and in-plane with the same optics as used to measure $\mathrm{PbS}$ thin films.

The morphology of the films was studied with a Hitachi S-4800 field emission scanning electron microscope (FESEM) and with atomic force microscopy (AFM) by using a Veeco Multimode V instrument. AFM tapping mode images were captured in air using silicon probes with a nominal tip radius of $10 \mathrm{~nm}$ and a nominal spring constant of 3 $\mathrm{N} / \mathrm{m}$ (NFESP from Bruker). Images were flattened to remove artifacts caused by a sample tilt and a scanner bow. Resistivities were determined from sheet resistance measured with four-point probe (CPS Probe Station, Cascade Microtech combined with a Keithley 2400 SourceMeter) from films deposited on soda lime glass.

Hall effect measurements of films on sapphire substrates were made at room temperature with an Ecopia Van der Pauw HMS-5000 measurement system. Time-of-flight elastic recoil detection analysis was performed using a $40 \mathrm{MeV}^{127} \mathrm{I}^{7+}$ beam. The incident angle of the beam was $16^{\circ}$, and the scattering angle was $40^{\circ}$. An FEI Quanta 3D 200i dual-beam microscope and standard lift-out procedures were used to prepare TEM cross-section specimens. An FEI Tecnai F20 microscope operated at $200 \mathrm{kV}$ was used for bright-field TEM imaging. An Oxford INCA 350 energy spectrometer connected to the FESEM was used for energy dispersive X-ray (EDS) measurements.

Transmittance of the films on sapphire substrates in the 190-3000 $\mathrm{nm}$ wavelength range was measured with an Agilent Cary 5000 spectrophotometer equipped with an internal diffuse reflectance measurement accessory (DRA-2500). The internal DRA consists of a $110 \mathrm{~mm}$ diameter integrating sphere with input and output apertures to perform reflectance and transmittance measurements. Sample of interest was mounted at the input aperture and the output aperture of the integrating sphere was covered with a standard reference material in the transmittance mode measurement. A Labsphere Spectralon SRM-99 diffuse reflectance standard was used for this purpose. Reference light was passed through the sample of interest when sample spectra were collected and the reference light intensity, in this case the emission light of Cary 5000, was measured without a sample. The scan speed was set to $10 \mathrm{~nm} / \mathrm{s}$ and step size to $1 \mathrm{~nm}$. Transmittance in the $3000-8000 \mathrm{~nm}$ wavelength range was measured with a Bruker Alpha II FTIR spectrometer. For Tauc plot construction direct allowed band gap was assumed for $\mathrm{PbS}$. 
Water vapor transmission (WVTR) tests were performed, and results were calculated according to the ASTM standard E 96/E 96M-05 desiccant method with modifications in custom-built chambers that comply with the standard requirements. The relative humidity $(\mathrm{RH})$ gradient used in these measurements was $0 / 75 \%$ instead of the $0 / 50 \%$ in the standard. The exposed sample surface area was limited to $5 \mathrm{~cm}^{2}$ with an adhesive PTFE/aluminum masking. The temperature was 23 ${ }^{\circ} \mathrm{C}$. The temperature and $\mathrm{RH}$ of the cabinet were measured by using a Rotronic RH meter (Bassersdorf, Switzerland) before each weighing. The experiments were performed by using three replicates. The WVTR was calculated from the weight gain via equation WVTR $=(\Delta W / t) / A$, where $\Delta W$ is the weight gain, $t$ the time, and $A$ the exposed surface area of the sample. The oxygen transmission rate and permeability were tested according to the ASTM standard D 3985-05 by using a Systech Illinois 8001 oxygen permeation analyzer (Johnsburg, IL). A mask (A Systech Illinois 8001 accessory) was used to limit the surface area of the samples to $5 \mathrm{~cm}^{2}$. The $\mathrm{O}_{2}$ partial pressure gradient was $1 \mathrm{~atm}$ with $\mathrm{N}_{2}$ on the receiving side, the temperature was set to $23{ }^{\circ} \mathrm{C}$, and the relative humidity of both gases $\left(\mathrm{N}_{2}\right.$ and $\left.\mathrm{O}_{2}\right)$ was $50 \%$. Two replicates of each sample were measured.

4.4. Computational Details. Reaction energies were calculated with density functional theory (DFT) in ORCA v4.2.1. ${ }^{92}$ Geometries were optimized by using Head-Gordon's range-separated hybrid functional modified by Najibi and Goerigk ${ }^{93}$ to include Grimme's dispersion correction with Becke-Johnson damping ${ }^{94,95}$ ( $\omega$ B97XD3(BJ)), Ahlrich's double- $\zeta$ split-valence quality basis set on all atoms (def2-SVP), ${ }^{96}$ and the Stuttgart ECP60MDF pseudopotential on $\mathrm{Pb}^{97}$ The resolution of the identity approximation for the Coulomb integrals with the chain of spheres approximation for the exchange term (RIJCOSX $)^{98}$ with the def2/J auxiliary basis set ${ }^{99}$ was used to speed up the self-consistent field (SCF) step of all calculations. Frequency analysis was used to confirm there were no imaginary vibrational modes, and the geometries were minima on the potential energy surface. Numerical frequency calculations were performed to work around a bug in the ORCA code involving analytical Hessian calculations together with the RIJCOSX approximation. Single-point calculations were then performed with a quadruple- $\zeta$ basis set (def2QZVPP) to obtain more accurate electronic energies to use with the thermochemical corrections from the previous frequency analysis. Enthalpy, entropy, and free energy changes of reaction were calculated by using Hess's law, with gas-to-solid transition enthalpy and entropy changes for $\mathrm{Pb}$ and $\mathrm{PbS}$ taken from the NIST Standard Reference Database Number $69 .^{74}$

\section{ASSOCIATED CONTENT}

\section{(s) Supporting Information}

The Supporting Information is available free of charge at https://pubs.acs.org/doi/10.1021/acs.chemmater.0c01887.

Energetics of reactions considered in the discussion of the mechanism of elemental lead formation; element concentrations measured with TOF-ERDA in PbS films; band gaps reported for $\mathrm{PbS}$ films in the literature; photographs of PbS films; GPC as a function of purge duration; thickness as a function of deposition cycles; thickness maps; impurity content as a function of deposition temperature; elemental depth profiles of the films; ALD study of $\mathrm{Pb}(\mathrm{dbda})-\mathrm{H}_{2} \mathrm{~S}$ process at $135^{\circ} \mathrm{C}$; FESEM images of $\mathrm{PbS}$ films deposited at different temperature and with different number of deposition cycles; optical properties of PbS films; in-plane and outof-plane XRD measurements of PbS films; Scherrer crystallite size as a function of temperature; XRD measurements of various samples with MAPI perovskite; transmission rates of $\mathrm{PbS}$ and $\mathrm{Al}_{2} \mathrm{O}_{3}$ covered $\mathrm{BOPET}$; description of the adapter used for BOPET depositions (PDF)

\section{AUTHOR INFORMATION}

\section{Corresponding Authors}

Mikko Ritala - Department of Chemistry, University of Helsinki, FI-00014 Helsinki, Finland; 1 orcid.org/0000-0002-62102980; Phone: +358504324945; Email: mikko.ritala@ helsinki.fi

Georgi Popov - Department of Chemistry, University of Helsinki, FI-00014 Helsinki, Finland; 이이.org/0000-0003-12338327; Phone: +358409130215; Email: georgi.popov@ helsinki.fi

\section{Authors}

Goran Bačic - Department of Chemistry, Carleton University, Ottawa, Ontario K1S 5B6, Canada; (1) orcid.org/0000-00032437-2418

Miika Mattinen - Department of Chemistry, University of Helsinki, FI-00014 Helsinki, Finland; 이이.org/0000-00034837-1823

Toni Manner - Department of Food and Nutrition, University of Helsinki, FI-00014 Helsinki, Finland

Hannu Lindström - VTT Technical Research Centre of Finland Ltd., FI-90590 Oulu, Finland

Heli Seppänen - Department of Electronics and Nanoengineering, Aalto University, FI-00076 Espoo, Finland

Sami Suihkonen - Department of Electronics and Nanoengineering, Aalto University, FI-00076 Espoo, Finland

Marko Vehkamäki - Department of Chemistry, University of Helsinki, FI-00014 Helsinki, Finland

Marianna Kemell - Department of Chemistry, University of Helsinki, FI-00014 Helsinki, Finland; 이이.org/0000-00023583-2064

Pasi Jalkanen - Department of Physics, University of Helsinki, FI00014 Helsinki, Finland

Kenichiro Mizohata - Department of Physics, University of Helsinki, FI-00014 Helsinki, Finland

Jyrki Räisänen - Department of Physics, University of Helsinki, FI-00014 Helsinki, Finland

Markku Leskelä - Department of Chemistry, University of Helsinki, FI-00014 Helsinki, Finland; 이이.org/0000-00015830-2800

Hanna Maarit Koivula - Department of Food and Nutrition, University of Helsinki, FI-00014 Helsinki, Finland

Seán T. Barry - Department of Chemistry, Carleton University, Ottawa, Ontario K1S 5B6, Canada; 이이.org/0000-00015515-4734

Complete contact information is available at:

https://pubs.acs.org/10.1021/acs.chemmater.0c01887

\section{Notes}

The authors declare no competing financial interest.

\section{ACKNOWLEDGMENTS}

We thank the Finnish Center of Excellence in Atomic Layer Deposition (ALDCoE 2012-2017) and additional support from the Academy of Finland (Decision Number 309552). We are grateful to the electron microscopy unit of the Institute of Biotechnology at the University of Helsinki for providing TEM instrument access. A part of the research was performed at the OtaNano - Micrometerova Nanofabrication Centre of Aalto University. G.P. acknowledges the doctoral program in Materials Research and Nanosciences (MATRENA) of the University of Helsinki as well as Emil Aaltonen foundation for 
funding and support. G.B. and S.T.B. acknowledge the QEIIOGSST program for funding and Carleton University for support. H.S. acknowledges the support from the Walter Ahlström Foundation.

\section{REFERENCES}

(1) Bloem, J.; Kröger, F. A. A Relation between Hardness and Stoichiometry in Lead Sulphide Single Crystals. Nature 1955, 175, 861-861.

(2) Wise, F. W. Lead Salt Quantum Dots: The Limit of Strong Quantum Confinement. Acc. Chem. Res. 2000, 33, 773-780.

(3) Moon, D. G.; Rehan, S.; Yeon, D. H.; Lee, S. M.; Park, S. J.; Ahn, S. J.; Cho, Y. S. A Review on Binary Metal Sulfide Heterojunction Solar Cells. Sol. Energy Mater. Sol. Cells 2019, 200, 109963.

(4) Yeon, D. H.; Mohanty, B. C.; Lee, C. Y.; Lee, S. M.; Cho, Y. S. High-Efficiency Double Absorber PbS/CdS Heterojunction Solar Cells by Enhanced Charge Collection Using a $\mathrm{ZnO}$ Nanorod Array. ACS Omega 2017, 2, 4894-4899.

(5) Safrani, T.; Kumar, T. A.; Klebanov, M.; Arad-Vosk, N.; Beach, R.; Sa'Ar, A.; Abdulhalim, I.; Sarusi, G.; Golan, Y. Chemically Deposited $\mathrm{PbS}$ Thin Film Photo-Conducting Layers for Optically Addressed Spatial Light Modulators. J. Mater. Chem. C 2014, 2, 9132-9140.

(6) Lee, S. M.; Jang, W.; Mohanty, B. C.; Yoo, J.; Jang, J. W.; Kim, D. B.; Yi, Y.; Soon, A.; Cho, Y. S. Experimental Demonstration of in Situ Stress-Driven Optical Modulations in Flexible Semiconducting Thin Films with Enhanced Photodetecting Capability. Chem. Mater. 2018, 30, 7776-7781.

(7) Carrillo-Castillo, A.; Salas-Villasenor, A.; Mejia, I.; AguirreTostado, S.; Gnade, B. E.; Quevedo-López, M. A. P-Type Thin Films Transistors with Solution-Deposited Lead Sulfide Films as Semiconductor. Thin Solid Films 2012, 520, 3107-3110.

(8) Navale, S. T.; Bandgar, D. K.; Chougule, M. A.; Patil, V. B. Facile Method of Preparation of PbS Films for $\mathrm{NO}_{2}$ Detection. RSC Adv. 2015, 5, 6518-6527.

(9) Beatriceveena, T. V.; Prabhu, E.; Sree Rama Murthy, A.; Jayaraman, V.; Gnanasekar, K. I. Highly Selective PbS Thin Film Based Ammonia Sensor for Inert Ambient: In-Situ Hall and Photoelectron Studies. Appl. Surf. Sci. 2018, 456, 430-436.

(10) Nykänen, E.; Laine-Ylijoki, J.; Soininen, P.; Niinistö, L.; Leskelä, M.; Hubert-Pfalzgraf, L. G. Growth of PbS Thin Films from Novel Precursors by Atomic Layer Epitaxy. J. Mater. Chem. 1994, 4, 14091412.

(11) Dasgupta, N. P.; Jung, H. J.; Trejo, O.; McDowell, M. T.; Hryciw, A.; Brongersma, M.; Sinclair, R.; Prinz, F. B. Atomic Layer Deposition of Lead Sulfide Quantum Dots on Nanowire Surfaces. Nano Lett. 2011, 11, 934-940.

(12) Jena, A. K.; Kulkarni, A.; Miyasaka, T. Halide Perovskite Photovoltaics: Background, Status, and Future Prospects. Chem. Rev. 2019, 119, 3036-3103.

(13) Chen, Q.; Wu, J.; Ou, X.; Huang, B.; Almutlaq, J.; Zhumekenov, A. A.; Guan, X.; Han, S.; Liang, L.; Yi, Z.; Li, J.; Xie, X.; Wang, Y.; Li, Y.; Fan, D.; Teh, D. B. L.; All, A. H.; Mohammed, O. F.; Bakr, O. M.; Wu, T.; Bettinelli, M.; Yang, H.; Huang, W.; Liu, X. All-Inorganic Perovskite Nanocrystal Scintillators. Nature 2018, 561, 88-93.

(14) Dong, Y.; Zou, Y.; Song, J.; Song, X.; Zeng, H. Recent Progress of Metal Halide Perovskite Photodetectors. J. Mater. Chem. C 2017, 5, 11369-11394.

(15) Chen, J.; Zhou, S.; Jin, S.; Li, H.; Zhai, T. Crystal Organometal Halide Perovskites with Promising Optoelectronic Applications. J. Mater. Chem. C 2016, 4, 11-27.

(16) Sim, K.; Jun, T.; Bang, J.; Kamioka, H.; Kim, J.; Hiramatsu, H.; Hosono, H. Performance Boosting Strategy for Perovskite LightEmitting Diodes. Appl. Phys. Rev. 2019, 6, 031402.

(17) Yu, W.; Li, F.; Yu, L.; Niazi, M. R.; Zou, Y.; Corzo, D.; Basu, A.; Ma, C.; Dey, S.; Tietze, M. L.; Buttner, U.; Wang, X.; Wang, Z.; Hedhili, M. N.; Guo, C.; Wu, T.; Amassian, A. Single Crystal Hybrid Perovskite Field-Effect Transistors. Nat. Commun. 2018, 9, 9.
(18) Kang, K.; Ahn, H.; Song, Y.; Lee, W.; Kim, J.; Kim, Y.; Yoo, D.; Lee, T. Perovskite Memory Devices: High-Performance SolutionProcessed Organo-Metal Halide Perovskite Unipolar Resistive Memory Devices in a Cross-Bar Array Structure. Adv. Mater. 2019, 31, 1970149.

(19) Xu, Z.; Liu, Z.; Huang, Y.; Zheng, G.; Chen, Q.; Zhou, H. To Probe the Performance of Perovskite Memory Devices: Defects Property and Hysteresis. J. Mater. Chem. C 2017, 5, 5810-5817.

(20) Koushik, D.; Verhees, W. J. H.; Kuang, Y.; Veenstra, S.; Zhang, D.; Verheijen, M. A.; Creatore, M.; Schropp, R. E. I. High-Efficiency Humidity-Stable Planar Perovskite Solar Cells Based on Atomic Layer Architecture. Energy Environ. Sci. 2017, 10, 91-100.

(21) Asundi, A. S.; Raiford, J. A.; Bent, S. F. Opportunities for Atomic Layer Deposition in Emerging Energy Technologies. ACS Energy Lett. 2019, 4, 908-925.

(22) Zardetto, V.; Williams, B. L.; Perrotta, A.; Di Giacomo, F.; Verheijen, M. A.; Andriessen, R.; Kessels, W. M. M.; Creatore, M. Atomic Layer Deposition for Perovskite Solar Cells: Research Status, Opportunities and Challenges. Sustain. Energy Fuels 2017, 1, 30-55.

(23) Seo, S.; Jeong, S.; Park, H.; Shin, H.; Park, N.-G. Atomic Layer Deposition for Efficient and Stable Perovskite Solar Cells. Chem. Commun. 2019, 55, 2403-2416.

(24) Brinkmann, K. O.; Gahlmann, T.; Riedl, T. Atomic Layer Deposition of Functional Layers in Planar Perovskite Solar Cells. Sol. RRL 2020, 4, 1900332.

(25) Raiford, J. A.; Oyakhire, S. T.; Bent, S. F. Applications of Atomic Layer Deposition and Chemical Vapor Deposition for Perovskite Solar Cells. Energy Environ. Sci. 2020, 13, 1997-2023.

(26) Database of ALD processes. DOI: DOI: 10.6100/alddatabase. http://www.atomiclimits.com/alddatabase/ (accessed Nov 15, 2019).

(27) Yu, X.; Yan, H.; Peng, Q. Improve the Stability of Hybrid Halide Perovskite via Atomic Layer Deposition on Activated Phenyl- $\mathrm{C}_{61}$ Butyric Acid Methyl Ester. ACS Appl. Mater. Interfaces 2018, 10, 28948-28954.

(28) Yun, S. J.; Kim, Y. S.; Park, S.-H. K. Fabrication of CaS:Pb Blue Phosphor by Incorporating Dimeric $\mathrm{Pb}^{2+}$ Luminescent Centers. Appl. Phys. Lett. 2001, 78, 721-723.

(29) Lee, Y.; Lee, S.; Seo, G.; Paek, S.; Cho, K. T.; Huckaba, A. J.; Calizzi, M.; Choi, D.; Park, J.-S.; Lee, D.; Lee, H. J.; Asiri, A. M.; Nazeeruddin, M. K. Efficient Planar Perovskite Solar Cells Using Passivated Tin Oxide as an Electron Transport Layer. Adv. Sci. 2018, 5, 1800130.

(30) Zheng, X.; Lei, H.; Yang, G.; Ke, W.; Chen, Z.; Chen, C.; Ma, J.; Guo, Q.; Yao, F.; Zhang, Q.; Xu, H.; Fang, G. Enhancing Efficiency and Stability of Perovskite Solar Cells via a High Mobility P-Type PbS Buffer Layer. Nano Energy 2017, 38, 1-11.

(31) Xie, L.; Zhang, T.; Zhao, Y. Stabilizing the MAPbI3 Perovksite via the In-Situ Formed Lead Sulfide Layer for Efficient and Robust Solar Cells. J. Energy Chem. 2020, 47, 62-65.

(32) Sutherland, B. R.; Hoogland, S.; Adachi, M. M.; Wong, C. T. O.; Sargent, E. H. Conformal Organohalide Perovskites Enable Lasing on Spherical Resonators. ACS Nano 2014, 8, 10947-10952.

(33) Sutherland, B. R.; Hoogland, S.; Adachi, M. M.; Kanjanaboos, P.; Wong, C. T. O.; McDowell, J. J.; Xu, J.; Voznyy, O.; Ning, Z.; Houtepen, A. J.; Sargent, E. H. Perovskite Thin Films via Atomic Layer Deposition. Adv. Mater. 2015, 27, 53-58.

(34) Popov, G.; Mattinen, M.; Hatanpää, T.; Vehkamäki, M.; Kemell, M.; Mizohata, K.; Räisänen, J.; Ritala, M.; Leskelä, M. Atomic Layer Deposition of $\mathrm{PbI}_{2}$ Thin Films. Chem. Mater. 2019, 31, 1101-1109.

(35) Bačić, G.; Zanders, D.; Mallick, B.; Devi, A.; Barry, S. T. Designing Stability into Thermally Reactive Plumbylenes. Inorg. Chem. 2018, 57, 8218-8226.

(36) Crowe, L. L.; Tolbert, L. M. Silica Passivation Efficiency Monitored by a Surface-Bound Fluorescent Dye. Langmuir 2008, 24, 8541-8546.

(37) Mattinen, M.; King, P. J.; Khriachtchev, L.; Meinander, K.; Gibbon, J. T.; Dhanak, V. R.; Räisänen, J.; Ritala, M.; Leskelä, M. LowTemperature Wafer-Scale Deposition of Continuous 2D SnS 2 Films. Small 2018, 14, 1800547. 
(38) Mattinen, M.; Popov, G.; Vehkamäki, M.; King, P. J.; Mizohata, K.; Jalkanen, P.; Räisänen, J.; Leskelä, M.; Ritala, M. Atomic Layer Deposition of Emerging 2D Semiconductors, $\mathrm{HfS}_{2}$ and $\mathrm{ZrS}_{2}$, for Optoelectronics. Chem. Mater. 2019, 31, 5713-5724.

(39) Huang, Y.; Liu, L.; Zhao, W.; Chen, Y. Preparation and Characterization of Molybdenum Disulfide Films Obtained by OneStep Atomic Layer Deposition Method. Thin Solid Films 2017, 624, 101-105.

(40) Hämäläinen, J.; Mattinen, M.; Mizohata, K.; Meinander, K.; Vehkamäki, M.; Räisänen, J.; Ritala, M.; Leskelä, M. Atomic Layer Deposition of Rhenium Disulfide. Adv. Mater. 2018, 30, 1703622.

(41) Tripathi, T. S.; Lahtinen, J.; Karppinen, M. Atomic Layer Deposition of Conducting CuS Thin Films from Elemental Sulfur. Adv. Mater. Interfaces 2018, 5, 1701366.

(42) Wei, Q.; Mukaida, M.; Naitoh, Y.; Ishida, T. Morphological Change and Mobility Enhancement in PEDOT:PSS by Adding CoSolvents. Adv. Mater. 2013, 25, 2831-2836.

(43) Snaith, H. J.; Grätzel, M. Enhanced Charge Mobility in a Molecular Hole Transporter via Addition of Redox Inactive Ionic Dopant: Implication to Dye-Sensitized Solar Cells. Appl. Phys. Lett. 2006, 89, 262114.

(44) Chia-Ching, W.; Cheng-Fu, Y. Investigation of the Properties of Nanostructured Li-Doped NiO Films Using the Modified Spray Pyrolysis Method. Nanoscale Res. Lett. 2013, 8, 33.

(45) Orton, J. W.; Powell, M. J. The Hall Effect in Polycrystalline and Powdered Semiconductors. Rep. Prog. Phys. 1980, 43, 1263-1307.

(46) Reid, O. G.; Yang, M.; Kopidakis, N.; Zhu, K.; Rumbles, G. Grain-Size-Limited Mobility in Methylammonium Lead Iodide Perovskite Thin Films. ACS Energy Lett. 2016, 1, 561-565.

(47) Kothiyal, G.; Ghosh, B. On Conductivity in Lead Chalcogenides. Prog. Cryst. Growth Charact. Mater. 1990, 20, 313-332.

(48) Allgaier, R. S.; Scanlon, W. W. Mobility of Electrons and Holes in $\mathrm{PbS}, \mathrm{PbSe}$, and PbTe between Room Temperature and $4.2 \mathrm{~K}$. Phys. Rev. 1958, 111, 1029-1037.

(49) Oh, S. J.; Berry, N. E.; Choi, J.-H.; Gaulding, E. A.; Paik, T.; Hong, S.-H.; Murray, C. B.; Kagan, C. R. Stoichiometric Control of Lead Chalcogenide Nanocrystal Solids to Enhance Their Electronic and Optoelectronic Device Performance. ACS Nano 2013, 7, 24132421.

(50) Ertekin, E.; Srinivasan, V.; Ravichandran, J.; Rossen, P. B.; Siemons, W.; Majumdar, A.; Ramesh, R.; Grossman, J. C. Interplay between Intrinsic Defects, Doping, and Free Carrier Concentration in $\mathrm{SrTiO}_{3}$ Thin Films. Phys. Rev. B: Condens. Matter Mater. Phys. 2012, 85, 195460.

(51) Riedl, H. R.; Schoolar, R. B. Photosensitivity in Epitaxial PbS Films. J. Appl. Phys. 1968, 39, 5086-5092.

(52) Yeon, D. H.; Lee, S. M.; Jo, Y. H.; Moon, J.; Cho, Y. S. Origin of the Enhanced Photovoltaic Characteristics of PbS Thin Film Solar Cells Processed at near Room Temperature. J. Mater. Chem. A 2014, 2, 20112-20117.

(53) Mohanty, B. C.; Bector, K.; Laha, R. Elucidating Doping Driven Microstructure Evolution and Optical Properties of Lead Sulfide Thin Films Grown from a Chemical Bath. Appl. Surf. Sci. 2018, 435, 444451.

(54) Hone, F. G.; Dejene, F. B. Six Complexing Agents and Their Effects on Optical, Structural, Morphological and Photoluminescence Properties of Lead Sulphide Thin Films Prepared by Chemical Route. J. Lumin. 2018, 201, 321-328.

(55) Cheraghizade, M.; Jamali-Sheini, F.; Yousefi, R. Optical, Electrical, and Photovoltaic Properties of PbS Thin Films by Anionic and Cationic Dopants. Appl. Phys. A: Mater. Sci. Process. 2017, 123, 1-9.

(56) Veena, E.; Bangera, K. V.; Shivakumar, G. K. Effect of Annealing on the Properties of Spray-Pyrolysed Lead Sulphide Thin Films for Solar Cell Application. Appl. Phys. A: Mater. Sci. Process. 2017, 123, 366.

(57) Abbas, M. M.; Shehab, A. A.-M.; Hassan, N.-A.; Al-Samuraee, A.K. Effect of Temperature and Deposition Time on the Optical Properties of Chemically Deposited Nanostructure PbS Thin Films. Thin Solid Films 2011, 519, 4917-4922.
(58) Azadi Motlagh, Z.; Azim Araghi, M. E. Effect of Annealing Temperature on Optical and Electrical Properties of Lead Sulfide Thin Films. Mater. Sci. Semicond. Process. 2015, 40, 701-707.

(59) Thangavel, S.; Ganesan, S.; Saravanan, K. Annealing Effect on Cadmium in Situ Doping of Chemical Bath Deposited PbS Thin Films. Thin Solid Films 2012, 520, 5206-5210.

(60) González-Lúa, R.; Escorcia-García, J.; Pérez-Martínez, D.; Nair, M. T. S.; Campos, J.; Nair, P. K. Stable Performance of Chemically Deposited Antimony Sulfide-Lead Sulfide Thin Film Solar Cells under Concentrated Sunlight. ECS J. Solid State Sci. Technol. 2015, 4, Q9Q16.

(61) Kaci, S.; Keffous, A.; Hakoum, S.; Trari, M.; Mansri, O.; Menari, $\mathrm{H}$. Preparation of Nanostructured PbS Thin Films as Sensing Element for $\mathrm{NO}_{2}$ Gas. Appl. Surf. Sci. 2014, 305, 740-746.

(62) Sadovnikov, S. I.; Gusev, A. I. Structure and Properties of PbS Films. J. Alloys Compd. 2013, 573, 65-75.

(63) Kotadiya, N. B.; Kothari, A. J.; Tiwari, D.; Chaudhuri, T. K. Photoconducting Nanocrystalline Lead Sulphide Thin Films Obtained by Chemical Bath Deposition. Appl. Phys. A: Mater. Sci. Process. 2012, $108,819-824$.

(64) Göde, F.; Güneri, E.; Emen, F. M.; Emir Kafadar, V.; Ünlü, S. Synthesis, Structural, Optical, Electrical and Thermoluminescence Properties of Chemically Deposited PbS Thin Films. J. Lumin. 2014, $147,41-48$.

(65) Silva Filho, J. M. C.; Ermakov, V. A.; Marques, F. C. Perovskite Thin Film Synthesised from Sputtered Lead Sulphide. Sci. Rep. 2018, 8, 1563.

(66) Cardona, M.; Greenaway, D. L. Optical Properties and Band Structure of Group IV-VI and Group V Materials. Phys. Rev. 1964, 133, A1685-A1697.

(67) Dasgupta, N. P.; Lee, W.; Prinz, F. B. Atomic Layer Deposition of Lead Sulfide Thin Films for Quantum Confinement. Chem. Mater. 2009, 21, 3973-3978.

(68) Gibson, A. F. The Absorption Spectra of Solid Lead Sulphide, Selenide and Telluride. Proc. Phys. Soc., London, Sect. B 1950, 63, 756767.

(69) Gibson, A. F. The Absorption Spectra of Single Crystals of Lead Sulphide, Selenide and Telluride. Proc. Phys. Soc., London, Sect. B 1952, $65,378-388$.

(70) Scanlon, W. W., Ed.; Polar Semiconductors. In Solid State Physics - Advances in Research and Applications; Elsevier: Amsterdam, 1959; Vol. 9, p 115.

(71) Suram, S. K.; Newhouse, P. F.; Gregoire, J. M. High Throughput Light Absorber Discovery, Part 1: An Algorithm for Automated Tauc Analysis. ACS Comb. Sci. 2016, 18, 673-681.

(72) Albanesi, E. A.; Peltzer y Blanca, E. L.; Petukhov, A. G. Calculated Optical Spectra of IV-VI Semiconductors $\mathrm{PbS}, \mathrm{PbSe}$ and $\mathrm{PbTe}$. Comput. Mater. Sci. 2005, 32, 85-95.

(73) Ivanov, I. L.; Steparuk, A. S.; Bolyachkina, M. S.; Tsvetkov, D. S.; Safronov, A. P.; Zuev, A. Y. Thermodynamics of Formation of Hybrid Perovskite-Type Methylammonium Lead Halides. J. Chem. Thermodyn. 2018, 116, 253-258.

(74) Shen, V. K., Siderius, D. W., Krekelberg, W. P., Hatch, H. W., Eds.; NIST Standard Reference Database Number 69; National Institute of Standards and Technology: Gaithersburg, MD, 2020.

(75) Ciccioli, A.; Latini, A. Thermodynamics and the Intrinsic Stability of Lead Halide Perovskites $\mathrm{CH}_{3} \mathrm{NH}_{3} \mathrm{PbX}_{3}$. J. Phys. Chem. Lett. 2018, 9, 3756-3765.

(76) Hultqvist, A.; Aitola, K.; Sveinbjörnsson, K.; Saki, Z.; Larsson, F.; Törndahl, T.; Johansson, E.; Boschloo, G.; Edoff, M. Atomic Layer Deposition of Electron Selective $\mathrm{SnO}_{\mathrm{x}}$ and $\mathrm{ZnO}$ Films on Mixed Halide Perovskite: Compatibility and Performance. ACS Appl. Mater. Interfaces 2017, 9, 29707-29716.

(77) Palmstrom, A. F.; Raiford, J. A.; Prasanna, R.; Bush, K. A.; Sponseller, M.; Cheacharoen, R.; Minichetti, M. C.; Bergsman, D. S.; Leijtens, T.; Wang, H.-P.; Bulović, V.; McGehee, M. D.; Bent, S. F. Interfacial Effects of Tin Oxide Atomic Layer Deposition in Metal Halide Perovskite Photovoltaics. Adv. Energy Mater. 2018, 8, 1800591. 
(78) Wang, H.-B.; Ma, D.-Y.; Ma, F.; Xu, K.-W. Impact of Ultrathin $\mathrm{Al}_{2} \mathrm{O}_{3}$ Interlayer on Thermal Stability and Leakage Current Properties of $\mathrm{TiO}_{2} / \mathrm{Al}_{2} \mathrm{O}_{3}$ Stacking Dielectrics. J. Vac. Sci. Technol., B: Nanotechnol. Microelectron.: Mater., Process., Meas., Phenom. 2012, 30, 040601.

(79) Cant, D. J. H.; Syres, K. L.; Lunt, P. J. B.; Radtke, H.; Treacy, J.; Thomas, P. J.; Lewis, E. A.; Haigh, S. J.; O’Brien, P.; Schulte, K.; Bondino, F.; Magnano, E.; Flavell, W. R. Surface Properties of Nanocrystalline PbS Films Deposited at the Water-Oil Interface: A Study of Atmospheric Aging. Langmuir 2015, 31, 1445-1453.

(80) Wilson, C. A.; Grubbs, R. K.; George, S. M. Nucleation and Growth during $\mathrm{Al}_{2} \mathrm{O}_{3}$ Atomic Layer Deposition on Polymers. Chem. Mater. 2005, 17, 5625-5634.

(81) Hirvikorpi, T.; Vähä-Nissi, M.; Mustonen, T.; Iiskola, E.; Karppinen, M. Atomic Layer Deposited Aluminum Oxide Barrier Coatings for Packaging Materials. Thin Solid Films 2010, 518, 26542658.

(82) Tsai, F. T.; Chao, C. K.; Jhong, K. J.; Chang, R. C. Characterization of Oxide Barrier Layers Prepared by Atomic Layer Deposition. Adv. Mech. Eng. 2017, 9, 1-7.

(83) Yoon, K. H.; Kim, H.; Koo Lee, Y.-E.; Shrestha, N. K.; Sung, M. M. UV-Enhanced Atomic Layer Deposition of $\mathrm{Al}_{2} \mathrm{O}_{3}$ Thin Films at Low Temperature for Gas-Diffusion Barriers. RSC Adv. 2017, 7, 56015609.

(84) Klumbies, H.; Schmidt, P.; Hähnel, M.; Singh, A.; Schroeder, U.; Richter, C.; Mikolajick, T.; Hoßbach, C.; Albert, M.; Bartha, J. W.; Leo, K.; Müller-Meskamp, L. Thickness Dependent Barrier Performance of Permeation Barriers Made from Atomic Layer Deposited Alumina for Organic Devices. Org. Electron. 2015, 17, 138-143.

(85) Gynane, M. J. S.; Harris, D. H.; Lappert, M. F.; Power, P. P.; Rivière, P.; Rivière-Baudet, M. Subvalent Group 4B Metal Alkyls and Amides. Part 5. The Synthesis and Physical Properties of Thermally Stable Amides of Germanium(II), Tin(II), and Lead(II). J. Chem. Soc., Dalton Trans. 1977, 2004-2009.

(86) Dasgupta, N. P.; Mack, J. F.; Langston, M. C.; Bousetta, A.; Prinz, F. B. Design of an Atomic Layer Deposition Reactor for Hydrogen Sulfide Compatibility. Rev. Sci. Instrum. 2010, 81, 044102.

(87) Nafees, M.; Ikram, M.; Ali, S. Thermal Stability of Lead Sulfide and Lead Oxide Nano-Crystalline Materials. Appl. Nanosci. 2017, 7, 399-406.

(88) Sadovnikov, S. I.; Kozhevnikova, N. S.; Rempel, A. A. Oxidation of Nanocrystalline Lead Sulfide in Air. Russ. J. Inorg. Chem. 2011, 56, 1864-1869.

(89) Yasaka, M. X-Ray Thin-Film Measurement Techniques V. Rigaku J. 2010, 26, 4.

(90) Langford, J. I.; Wilson, A. J. C. Scherrer after Sixty Years: A Survey and Some New Results in the Determination of Crystallite Size. J. Appl. Crystallogr. 1978, 11, 102-113.

(91) Sreemany, M.; Sen, S. A Simple Spectrophotometric Method for Determination of the Optical Constants and Band Gap Energy of Multiple Layer $\mathrm{TiO}_{2}$ Thin Films. Mater. Chem. Phys. 2004, 83, 169177.

(92) Neese, F. Software Update: The ORCA Program System, Version 4.0. Wiley Interdiscip. Rev.: Comput. Mol. Sci. 2018, 8, 8.

(93) Najibi, A.; Goerigk, L. The Nonlocal Kernel in van Der Waals Density Functionals as an Additive Correction: An Extensive Analysis with Special Emphasis on the B97M-V and $\Omega$ B97M-V Approaches. J. Chem. Theory Comput. 2018, 14, 5725-5738.

(94) Grimme, S.; Antony, J.; Ehrlich, S.; Krieg, H. A Consistent and Accurate Ab Initio Parametrization of Density Functional Dispersion Correction (DFT-D) for the 94 Elements H-Pu. J. Chem. Phys. 2010, $132,154104$.

(95) Grimme, S.; Ehrlich, S.; Goerigk, L. Effect of the Damping Function in Dispersion Corrected Density Functional Theory. J. Comput. Chem. 2011, 32, 1456-1465.

(96) Weigend, F.; Ahlrichs, R. Balanced Basis Sets of Split Valence, Triple Zeta Valence and Quadruple Zeta Valence Quality for H to Rn: Design and Assessment of Accuracy. Phys. Chem. Chem. Phys. 2005, 7, 3297.
(97) Metz, B.; Stoll, H.; Dolg, M. Small-Core MulticonfigurationDirac-Hartree-Fock-Adjusted Pseudopotentials for Post- d Main Group Elements: Application to $\mathrm{PbH}$ and PbO. J. Chem. Phys. 2000, $113,2563-2569$.

(98) Neese, F.; Wennmohs, F.; Hansen, A.; Becker, U. Efficient, Approximate and Parallel Hartree-Fock and Hybrid DFT Calculations. A 'Chain-of-Spheres' Algorithm for the Hartree-Fock Exchange. Chem. Phys. 2009, 356, 98-109.

(99) Weigend, F. Accurate Coulomb-Fitting Basis Sets for H to Rn. Phys. Chem. Chem. Phys. 2006, 8, 1057. 